\title{
Finansal Raporlama Kalitesi İle Denetim Kalitesi Arasındaki İlişkinin Türk Bankacılık Sektörü Çerçevesinde İncelenmesi*
}

\author{
Merve ACAR **
}

\section{ÖZET}

Bu çalışmada 2003-2018 dönemi çerçevesinde Türkiye'de faaliyet gösteren bankaların (yatırım ve kalkanma bankaları hariç) finansal raporlama kalitesi ile denetim kalitesi arasındaki ilişki araşttrılmış̧tır. Çalışma kapsamında, denetim kalitesi, denetim firması büyüklüğü ve denetçi uzmanlı̆̆ı aracı değisşkenleri ile ve finansal raporlama kalitesi ise kar yönetimi uygulamaları aractlğı̆yla ölçülmüş̧ür. Elde edilen sonuçlara göre denetim kalitesinin kar yönetim uygulamaları üzerinde anlaml kıstlayıcı etkisi, diğer bir ifadeyle finansal raporlama kalitesi üzerinde anlaml pozitif etkisi bulunmaktadır. Denetim kalitesi göstergelerinin "beklenen zarar karşıllkları giderleri" nin ihtiyari kismıyla karşıllklar öncesi net kar arasındaki ilişkiyi anlamlı şekilde zayıflattığ gözlemlenmişstir. Diğer taraftan, ayrı olarak analiz edildiğinde her iki denetim kalitesi aracının da finansal raporlama kalitesini arttırdığı; ancak eş zamanlı analizlerde finansal raporlama kalitesi üzerindeki denetim kalitesinin olumlu ayrıştırıcı etkisinin finansal sektörde uzmanlaşmış denetim firmalarından kaynaklandiğı da elde edilen sonuçlar arasındadır.

Anahtar Kelimeler: Denetim Kalitesi, Finansal Raporlama Kalitesi, Denetçi Uzmanlığı, Kar Yönetimi, Beklenen Zarar Karşıllkkları, Beklenen Zarar Karşıllkları Giderleri

JEL Sinıflandirması: G14, G21, M41, M42, C12, N22

\section{Investigating The Relationship Between Financial Reporting Quality And Audit Quality In Frame Of Turkish Banking Sector}

\section{ABSTRACT}

This study examines the impact of audit quality on financial reporting quality for banks operated in Turkey for the period 2003-2018. Throughout the study, audit quality is proxied by auditor size, auditor specialization and financial reporting quality is proxied by earnings management practices. Results show that both auditor type and auditor reputation per financial system restrict the motivation of managers for earnings manipulation. In particular, significant relationship between earning (before provision) and loan loss provision is reported, suggesting that bank managers use LLP to smooth earnings for the sample period. However, auditor type and industry specialization (whether the audit firm is specialized in financial sector or not) significantly decrease discretionary loan loss provisions, which is a proxy for the income smoothing hypothesis. Besides, it is observed that in seperate analyses both audit quality measures increase the financial reporting quality; however, in simultaneous equation this relationship is moderated by auditor specialization in financial sector.

Keywords: Audit quality, Finnacial Reporting Quality, Auditor Specialization, Earnings Management, Loan Loss Provisions

Jel Classification: G14, G21, M41, M42, C12, N22

\footnotetext{
* Makale Gönderim Tarihi: 15.01.2020, Makale Kabul Tarihi: 27.02.2020 , Makale Türü: Nicel Araştırma

** Doktor Öğretim Üyesi, Ankara Yıldırım Beyazıt Üniversitesi, İşletme Fakültesi, macar@ybu.edu.tr, Araştırma Makalesi, ORCID No: 0000-0001-5312-7935.
} 


\section{GíRiş}

Ekonominin bel kemiklerinden olan bankaların ekonomik sistem içindeki yeri ve üstlendiği rol oldukça önemlidir. $\mathrm{Bu}$ önemin büyüklüğü en çok da finansal sıkıntı zamanlarında kendini göstermektedir (Bernanke, 1983: 262, Vauhkonen, 2011: 40). Bankalar özellikle piyasaya fon sağlama işlevleri ve sektördeki diğer bankalarla kurdukları ikili ilişkiler nedeniyle genel ekonomi üzerinde diğer sektörlerdeki işletmelere göre daha fazla etkiye neden olmakta ve maruz kalmaktadırlar. Özellikle büyük ölçekli banka başarısızlıkları ekonomilere ciddi maddi külfet getirmekte, kaynak dağılımını olumsuz etkilemekte ve bu doğrultuda mevduat sahipleri birikimlerine, borçlular ise kredi kaynağına erişimde sorun yaşamaktadır. Nitekim yaşanan son global krizin de en yıkıcı etkileri finansal sektör aracılığıyla ve finansal sektör üzerinde gerçekleşmiştir.

Bankacılık sektörü sahip olduğu bu önem ve diğer sektörlerden ayrışan faaliyet dinamikleri dolayısıyla aslında en fazla düzenleme ve ciddi düzeyde kontrolün görüldüğü sektörlerden biridir (Dahl vd., 1998: 15, Chalermchatvichien vd., 2014: 220). Ancak yine de muhasebe ilke ve politikalarının sağladığı esneklikler, banka yöneticilerinin de kimi zaman bu esnekliklerin kişisel ya da kurumsal menfaatler çerçevesinde kullanılmasına ve finansal tablo kullanıcılarının yanıltılmasına neden olmaktadır. Bu çerçevede yapılan düzenlemelere ek olarak gerçekleştirilecek bağımsız denetim sürecinin banka finansal raporlama kalitesini olumlu yönde etkileyeceği beklentiler dahilindedir (GAO, 1991: 30). Diğer taraftan banka denetiminin diğer sektörlerde faaliyet gösteren firmaların denetiminden daha zor ve karmaşık olduğu söylenebilir (Billingsey vd., 2009: 185). Amerikan Yeminli Mali Müşavirler Enstitüsü (American Institute of Certified Public Accountants') 2006 senesinde yayımladığı raporda "beklenen zarar karşılıkları" (loan loss allowance) ve "beklenen zarar karşılıkları giderleri" (loan loss provisions) kaleminin denetçiler tarafından en fazla sıkıntı ve usulsüzlükle karşılaşılan hesaplar olduğunu belirtmiştir. Raporlama açısından aradaki farkın beklenen zarar karşılıklarının bilançoda, beklenen zarar karşılıkları giderlerinin ise gelir tablosunda raporlandığını söylemek mümkündür. Beklenen zarar karşılıkları giderleri cari dönemde sorunlu olması beklenen krediler için ayrılan karşılık tutarı ile diğer döneme ilişkin değişimi içerirken, beklenen zarar karşıllkları bahsi geçen gelir tablosu kaleminin bilançodaki kümülatif gösterimidir. Bu çerçevede bankacılık sektörünün en önemli ve tutar olarak en yüksek tahakkuk kalemi olan beklenen zarar karşılıkları (McNichols, 2001: 316) bağımsız denetim sürecinde denetçiler için önemli bir çalışma alanı olduğu apaçık ortadadır. Nitekim 2017 senesinden itibaren ülkemizde de zorunlu hale getirilen kilit denetim konularına ilişkin açıklamalarda denetlenen bankalar bazında krediler ve beklenen zarar karşılıklarının çoğunlukla altı çizilen kalemler olduğu görülmektedir (Yanık ve Karataş, 2017: 23, Akdoğan ve Bülbül, 2019: 20). İlgili literatür incelendiğinde de bankacılık sektörünün beklenen zarar karşılıkları ve baklenen zarar karşılıkları giderleri aracılığıyla kar yönetimi ve sermaye yönetimi faaliyetlerinde bulundukları görülmektedir.

$\mathrm{Bu}$ kapsamda bu çalışmanın temel amacı finansal raporlama kalitesi ile denetim kalitesi arasındaki ilişkiyi Türk Bankacılık Sektörü ekseninde ortaya koymaktır. Yapılan çalışmalarla uyumlu olarak finansal raporlama kalitesinin ölçümünde kar yönetimi uygulamaları dikkate alınmıştır. Bankacılık sektörü çalışmanın odak noktası olduğu için de sektörde en fazla karşılaşılan ve araştırmalara konu edilen "karın istikrarlı gösterilmesi”" kar yönetimi uygulaması test edilmiştir. Denetim kalitesinin tespitinde ise ülkemiz veri erişim olanakları çerçevesinde denetçi büyüklüğü ve denetçi uzmanlığı analizlere dahil edilmiştir. 
Uluslararası uygulamalarda da "Büyük Dört" denetim şirketi olarak anılan Deloitte, PricewaterhouseCoopers, Ernst\&Young ve KPMG denetim şirketleri yapılan ampirik çalışmalarda denetçi büyüklüğü tespitinde referans noktası olarak alınmaktadır. Bu argümanla uyumlu olarak yapılan bu çalışmada da denetçi büyüklüğünün tespitinde "Büyük Dört" denetim şirketi baz alınmıştır. Denetçi uzmanlığı ise bu çalışmada denetim kalitesi ölçümünde aracı değişken olarak kullanılan diğer değişkendir. Literatür belli sektörlerde uzmanlaşan denetim kadrosunun hileli finansal raporlamayı önemli ölçüde azalttığı ve finansal raporlama kalitesini arttırdığı yönündedr (Carcello ve Nagy, 2003: 655, Krishnan, 2003: 111, 2005: 24, Kanagaretnam vd. 2010: 2321). Bu açıdan bakıldığında denetçi uzmanlığı test edilen ampirik modellerde söz konusu bankanın finansal tablo denetimini gerçekleştiren denetim şirketinin bankacilık sektöründe uzman olup olmama durumu ile ilişkilendirilmiştir. Toparlamak gerekirse, yapılan bu çalışmada 2003-2018 dönemi finansal tabloları incelenen ve Türkiye'de faaliyet gösteren 22 bankanın ilgili verileri kullanılarak finansal raporlama kalitiesi ile denetim kalitesi arasındaki ilişki sorgulanmıştır.

$\mathrm{Bu}$ çalışmadan literatüre ve uygulayıcılara dair fayda beklentileri ise şu şekilde sıralanabilir. Öncelikle 2008 global krizinin etkileri henüz özellikle de Türkiye gibi gelişmekte olan ülke ekonomileri için ortadan kalkmış değildir. Bu durum bankalar üzerindeki baskı ve kontrol mekanizmalarını daha da arttırmakta ve finansal tablo kullanıcılarının da finansal raporlama kalitesi ve denetçinin bu süreçteki rolünü daha fazla önemsemesini de beraberinde getirmektedir. Bu kapsamda yapılan çalışma literatüre katkı yapma yanında küçük yatırımcıyı da bilgilendirme motivasyonu taşımaktadır. Diğer taraftan finansal raporlama kalitesi ile denetim kalitesi arasındaki ilişki son zamanların dikkat çeken konularından biri olmakla birlikte bankacılık sektörü üzerine yapılan çalışmalar oldukça kısıtlıdır. Ülkemizde ise henüz bu alanda yapılan bir çalışmaya rastlanmamıştır. Bu çerçevede elde edilen sonuçların paydaşlara faydalı olması beklentisiyle bu çalışma yapıılmış ve denetim kalitesinin finansal raporlama kalitesi üzerindeki olası etkileri ortaya konulmaya çalışılmıştır.

Giriş ile başlayan çalışmanın ikinci bölümünde finansal raporlama ve denetim kalitesine ilişkin kavramsal çerçeve çizilmeye çalışılmıştır. Araştırmanın yöntemi ve ampirik model tasarımına ait detaylar üçüncü bölümde verilmiş, devamında örneklem hipotezler ve ampirik sonuçlar raporlanmıştır. Son olarak dördüncü bölümde sonuçların özetlenmesi, çalışmanın kısıtları ve gelecek araştırma önerileri ile çalışma sonlandırılmıştır.

\section{LITERATÜR TARAMASI}

Finansal tablolarda kalite kavramı net olarak bir tanım ya da ölçüte sahip olmamakla birlikte Gençoğlu ve Ertan (2012), finansal raporlama kalitesini, finansal tablolarda yer alan bilgilerin, finansal tablo kullanıcılarının ihtiyaçlarına uygun olması olarak tanımlamışlardır. Nitekim muhasebe bilgisinin taşıması gereken özellikler uluslararası finansal raporlama standartları kurulu tarafından da düzenlenerek "ihtiyaca uygunluk" ile "gerçeğe uygun sunum" birincil seviye (temel) niteliksel özellikler olarak belirlenmiştir. Bu kapsamda ihtiyaca uygunluk muhasebe bilgisinin karar alma sürecindeki önemini vurgularken, gerçeğe uygun şekilde sunum ise raporlarda sunulan muhasebe bilgisinin tam, tarafsız ve dürüst bir şekilde sunulmasına dikkat çekmektedir (KGK, 2018). Bu çerçevede finansal raporlama kalitesine ilişkin literatür incelendiğinde, reel ya da finansal sektör farkı olmaksızın, finansal raporlama kalitesinde ölçüt olarak kar yönetimi ya da daha geniş tanımıyla muhasebeleştirme manipülasyonlarının kastedildiği görülmektedir (Ma, 1988: 490, DeFond ve Jiambalvo, 1994: 164, Jonas ve Blanchet, 2000: 358, Johnson vd., 2002: 642, Cohen vd., 2004: 105, Doyle vd., 
2007: 1151, Biddle vd., 2009: 118, Chen vd., 2010: 225, Barth ve Landsman, 2010: 405, Iatridis, 2010: 197, Chen vd., 2011: 1260, Jin vd., 2011: 2812, Huang ve Wang, 2013: 149, Abata, 2015: 3, Abbott vd., 2016: 7, Gaynor vd., 2016: 8, Uwuigbe vd., 2016: 190, Dal Maso vd., 2018: 405, Delis vd., 2018: 300, Bratten vd., 2019: 300).

Muhasebeleştirme manipülasyonları arasında gösterilen kâr yönetimi en genel şekliyle, yöneticilerin şirket performansı hakkında piyasa katılımcılarını yanlış yönlendirmek ya da raporlanan kâr bilgisine göre şekillenen bazı sözleşmelerden doğan sonuçları etkilemek amaciyla, kendilerine tanınan karar verme yetkisini kullanarak, finansal raporlarda yer alan bilgileri aslına uygun bir şekilde yayınlamamalarıdır (Mulford ve Comiskey 2011: 57). Kar yönetimi uygulamaları ise reel sektör ve finansal sektörde faaliyet gösteren firmalar için farklı dinamiklere (kar arttırıcı, kar azaltıcı ya da karın istikrarlı hale getirilmesi) sahip olsa da ortak uygulama kar yönetiminin ihtiyari tahakkuklar aracılığıyla yapılmasıdır (Healy ve Wahlen, 1999: 367, Dechow ve Skinner, 2000: 242, McNichols, 2001: 319). Tahakkuklar yapis1 itibarıyla ihtiyari ve ihtiyari olmayan tahakkuklar olarak ikiye ayrılmakta ve kar yönetimi tespiti de bu ayrışmadan yola çıkılarak tahmin edilmektedir (Shah ve Butt, 2009: 630). Toplam tahakkukların ihtiyari olmayan kısmı firmanın olağan faaliyetlerinin bir sonucu olarak ortaya çıkarken, ihtiyari tahakkuklar finansal raporlama sürecinde yöneticilerin takdir yetkileri ile şekillenmektedir (McNichols ve Wilson, 1988: 21, Cohen vd. 2004: 89). Kullanılan bu takdir yetkisi nedeniyle de ihtiyari tahakkukların tespiti ve test edilmesi kar yönetimi çalışmalarının temelini oluşturmaktadır. Bu çalışmaya konu olan sektör finansal sektör olduğu için kar yönetimi uygulamaları, daha geniş ifadeyle finansal raporlama kalitesi finansal sektör açısından ele alınacaktır. Finansal sektör (genellikle bankacılık sektörü) üzerine yapılan kar yönetimi çalışmaları genellikle kayıp karşılıkları (beklenen zarar karşılıkları/beklenen zarar karşılıkları giderleri) (Ahmed vd., 1999: 2, Beaver ve Engel, 1996: 178, Greenawalt ve Sinkey, 1988: 302, Ma, 1988: 488) ve menkul kıymet işlemlerinden elde edilen kar (Beatty vd., 2002: 232) üzerine yoğunlaşmakla beraber son zamanlarda aktiflerin menkul kıymetleştirilmesi sonucu gerçeğe uygun değer üzerinden değerlenmeleri sürecinde elde edilen getiriler, finansal araçların sınıflandırılması ve ölçülmesi gibi konular da kar yönetimi kapsamında ele alınmaya başlanmıştır (Dechow vd., 2010: 2, Huizinga ve Laeven, 2012: 615, Song vd., 2010: 1376). Bu çalışma kapsamında ise kar yönetimi uygulamaları bankacılık sektöründe en fazla test edilen "karın istikrarlı gösterilmesi" hipotezine yönelik olarak ele alınacaktır. En genel ifadeyle karın istikrarlı gösterilmesi, uygun muhasebe ilke, yöntem ve politikaları aracılığıyla kârdaki dalgalanmaların azaltılarak hedef kâr düzeyine çekilmesidir (Copeland 1968: 105). Karın istikrarlı gösterilmesi hipotezi gerek reel sektör gerek finansal sektör için (Bao ve Bao, 2004: 1526, Beidleman, 1973: 655, Breton ve Stolowy, 2000: 3, Fudenberg ve Tirole, 1995: 78, Imhoff, 1979: 120, Martinez ve Castro, 2011: 3, Michelson vd., 1995: 1180, Stolowy ve Breton, 2004: 5, Trueman ve Titman, 1988: 128) en fazla test edilen kar yönetimi uygulamalarından biridir. Bahsi geçen kar yönetimi uygulaması ise çoğunlukla "kayıp kredi karşılıkları" (loan loss provisions) ya da ülkemizde faaliyet gösteren bankaların finansal tablolarında yer aldığı şekliyle "özel karşılıklar" (banka finansal tablolarının 2003-2017 yıllarını kapsayan dönemlerinde) ya da "beklenen zarar karşılıkları" (banka finansal tablolarının 2018 yılı ve sonrasını kapsayan dönemleri) aracılığıyla yapılmaktadır. Ülkemizde kredilerin sınıflandırılması ve bunlar için ayrılacak karşılıklara ilişkin usul ve esaslara kısaca değinilirse 2003-2017 yılları arasında BDDK'nın yayımlamış olduğu "Bankalarca Kredilerin ve Diğer Alacakların Niteliklerinin Belirlenmesi ve Bunlar İçin Ayrılacak Karşılıklara İlişkin Usül ve Esaslar Hakkında Yönetmelik" çerçevesinde kredilerin sınıflandırılması (Birinci Grup - Standart Nitelikli Krediler ve Diğer 
Alacaklar, İkinci Grup - Yakın İzlemedeki Krediler ve Diğer Alacaklar, Üçüncü Grup - Tahsil İmkânı Sınırlı Krediler ve Diğer Alacaklar, Dördüncü Grup - Tahsili Şüpheli Krediler ve Diğer Alacaklar, Beşinci Grup - Zarar Niteliğindeki Krediler ve Diğer Alacaklar) ve üçüncü, dördüncü ve beşinci grup kredileri karşılıkların ayrılması düzenlenmekteydi. İlgili yönetmelik bankaların gerek kredilerin özel karşılık ayrılan kredi grupları arasında (üçüncü, dördüncü ve beşinci grup krediler) sınıflandırılması gerek kredilere ayrılacak karşılık tutarının belirlenmesi konusunda belli sınırlar dahilinde karar vermelerine olanak tanımaktaydı. 01.01.2018'den itibaren ise UFRS 9: Finansal Araçlar Standardının kabulü ile ve bahsi geçen yönetmeliğe dahil edilmesiyle özel karşılıklar yerini beklenen zarar karş1lıklarına bırakmıştır. Sözkonusu düzenlemeyle birlikte değer düşüklüğü kapsamındaki finansal aracın kredi riskinde ilk defa finansal tablolara alınmasından bu yana önemli bir değişim olup olmadığı değerlendirilir. $\mathrm{Bu}$ değerlendirme ise büyük ölçüde temerrüt riskine dayandırılır. İlgili risklerin belirlenmesi ve karşılık oranlarının saptanmasında ise yeni düzenlemenin finansal tablo hazırlayanların takdir yetkisini genişlettiği söylenebilir.

Kayıp kredi karşılıklarının, karı istikrarlı göstermek için kullanılan yöntem ya da araçların sahip olması gereken özellikleri taşıması da bu hesap kalemini kar yönetimi uygulamaları için uygun bir araç haline getirmektedir (Copeland, 1968: 110). Kayıp karşılıklarının taşıdığı bahsi geçen bu özellikler ise;

i. Finansal tablo hazırlayıcılarının kredi karşılığını belirlemede karar verme özgürlüğü ve yetkisine sahip olmaları,

ii. İşlemin izleyen dönemlerde tekrarlanma zorunluluğu olmaması (Her dönem karşı1ık ayırmak ya da ayırmamak gibi bir zorunluluk yoktur.)

iii. Yapılan işlemin genel kabul görmüş muhasebe ilke ve politikalarına aykırı bir durum teşkil etmemesi ve

iv. Karşılık ayırma işleminin işletme dışı üçüncü kişilerle yapılan bir işlem değil hesapların kendi içinde oluşturulan bir durum olması (hesaplar arası düzenleme) şeklinde siralanabilir.

$\mathrm{Bu}$ özelliklerin yanında kayıp karşılıklarının nakit çıkışı gerektirmeyen giderlerden olması da bu kalemin karı istikrarlı göstermek için etkili bir araç olmasını sağlamaktadır (Rivard vd., 2003: 275).

Karın istikrarlı gösterilmesinin analiz edildiği çalışmaların genelinde, raporlanan kar rakamı ile (vergi sonrası karşılık öncesi kar) ayrılan kredi karşılıkları arasındaki ilişki incelenmektedir. Karın istikrarlı gösterilmesi hipotezi çerçevesinde beklenen, bu iki değişken arasında anlamlı pozitif ilişki olmasıdır. Buna göre karın yüksek olduğu zamanlarda arttırılan kredi karşılıkları kardaki sert yükselişi, karda düşüş olduğu zamanlarda ise azaltılan kredi karşılıkları kardaki sert düşüşü yumuşatarak istikrarlı bir kar serisi yaratacaktır.

Finansal sektör kapsamında ise karın istikrarlı gösterilmesine dair yapılan ilk çalışmanın Scheiner'e (1981: 1919) ait olduğu tahmin edilmektedir. Scheiner (1981: 2122), ilgili çalışmada kar ile beklenen zarar karşılıkları giderleri arasında anlamlı bir ilişki ortaya koyamamış; ancak, yöneticilere sağlanan karar verme yetkisinin daha fazla önemsenmesi gerektiğini vurgulayarak bu çalışma alanına olan ilgiyi arttırmıştır. Karın istikrarlı 
gösterilmesi hala gerek modelleme gerek açıklayıcılarının daha geçerli ve güvenilir bir şekilde ortaya konulabilmesi amacıyla kar yönetimi literatürünün en fazla ilgi çeken ve test edilen alt dalı olmakla beraber yapılan çalışmalar genellikle ihtiyari tahakkuklar ile kar arasında olumlu ilişki raporlamakta ve kar yönetimi uygulamalarının varlığını desteklemektedir (Ali vd., 2015: 54, Beaver ve Engel, 1996: 200, Blasco ve Pelegrin, 2006: 366, Bushman ve Williams, 2012: 390, Cavallo ve Majnoni, 2002, Collins vd., 1995: 285, Curcio ve Hasan, 2015: 44, El Sood, 2012: 66, Greenawalt ve Sinkey, 1988: 313, Hasan ve Wall, 2004: 145, Kanagaretnam vd., 2003: 75, Kanagaretnam vd., 2004: 880, Kwak vd., 2009: 238, Lobo ve Yang 2001: 245, Rivard vd., 2003: 290, Abu-Serdaneh, 2018: 690, Ozili, 2018: 62, Osma vd., 2019: 170, Vishnani vd., 2019: 290).

İhtiyari tahakkukların bankacılık sektöründe kullanıldığı bir diğer alan ise "sermaye yönetimi”" uygulamalarıdır. Bankacılık sektörü açısından ele alındığında, sermaye; bankanın gerçekleştirdiği işlemler ve faaliyetleri dolayısıyla maruz kaldığı risklerin gerçekleşmesi halinde uğranılacak zararların telafi edilmesi için doğrudan güvence sağlayan bir kaynaktır. Dolayısıyla banka sermayesi, mevduat sahiplerine ve kredi verenlere sağladığı güvenle bankalara ve finansal sisteme bir bütün olarak güvence sağlamaktadır (Anderson ve Fraser, 2000: 1378). Finansal yapı itibariyle diğer sektörlerden ayrışan finansal sektörde, bankalar faaliyete başladıkları dönemde yoğunlukla öz sermayelerini kullanan ancak daha sonrasında mevduatlarını arttırma gayretiyle, toplam kaynakları içinde düşük tutarlarda öz sermayeye sahip yabancı kaynağa dayalı çalışan kuruluşlar olarak karşımıza çıkar. Ancak bu finansal bileşim içinde özsermaye/mevduat oranı hakkında kesin bir şey söylemek mümkün olmamaktadır. Yaşanan yerel bazlı ve global finansal krizler ile artan banka iflaslarının ekonomi üzerindeki olumsuz etkisi değerlendirildiğinde sermaye yönetimi konusu daha da önem kazanmaya başlamıştır. Bu kapsamda, 1988 yılında Basel Komitesi tarafından başlangıçta sadece uluslararası faaliyet gösteren bankaları kapsayan ancak sonrasında tüm dünya ülkeleri ve tüm bankaları da içine alan, riskli faaliyetler ile tutulan sermaye arasındaki ilişki konusunda bankalara rehberlik eden Basel Uzlaşısı yürürlüğe girmiştir. Basel Uzlaşısı ile hazırlanan ve yürürlüğe konulan Basel 1 ülkeler için sermaye yeterliliğinin hesaplanması konusunda ortak bir uygulama geliştirmeyi ve uluslararası platformda geçerli olacak asgari bir sermaye yeterlilik oranı oluşturmayı amaçlamıştır (Erdoğan, 2014: 150). Sermaye yeterlilik oranlarının hesaplanmasında kullanılan hesaplamalarda önemli bir kalem olarak karşımıza çıkan kayıp kredi ve özel karşılıkların (beklenen zarar karşılıkları) sermaye yönetimi aracı olarak manipülatif güdülerle kullanıldığı yönünde pek çok çalışma (Beatty vd., 1995: 255, Anandarajan vd., 2005: 70, Bouvatier ve Lepetit, 2008: 518, Leventis vd., 2011: 115, Magnis ve Iatridis, 2017: 349) mevcuttur; ancak, henüz bir fikir birliğine ulaşılamamıştır.

$\mathrm{Bu}$ çalışmanın temel motivasyonu ise finansal raporlama kalitesi üzerinde denetim kalitesinin olası etkilerini ortaya koymaktır. Tartışmalı bir alan olmakla beraber denetim kalitesine ilişkin en kapsamlı ve kabul edilebilir tanımlamanın DeAngelo (1981:185) tarafından yapıldığını söylemek mümkündür. Bu çerçevede, denetim kalitesi; “denetimi gerçekleştiren denetçi tarafından i) müşterisinin muhasebe sisteminde tespit ettiği bir ihlalin ve ii) bu ihlalin raporlanabilme olasılığının piyasa tarafından değerlendirilmesidir" şeklinde tanımlamıştır (DeAngelo, 1981: 183). Söz konusu tanımda denetim kalitesinin iki önemli boyutu ön plana çıkmaktadır. Bunlardan ilki, denetçinin hileyi ortaya çıkarabilme becerisi ve yeterliliği ve diğeri de bu hata ya da hileyi kamuoyu ile paylaşabilme sürecindeki bağımsızlığıdır. DeAngelo (1981) ve sonrasında Palmrose (1988) denetim kalitesini daha çok finansal raporlama kalitesi çerçevesinde ele almıştır; diğer taraftan Titman ve Trueman (1986) 
denetçinin yatırımcılara sunduğu bilginin doğruluğu ve bütünlüğü olarak tanımlanan denetim kalitesi, Knechel (2009) tarafından daha normatif bir bakış açısıyla erişilen güvence düzeyi olarak tanımlanmaktadır. Yapılan tanımlar ve beraberinde geliştirilen ölçütler doğruyu yansıtmakla beraber bütünlük açısından zayıf kalındığı yönünde fikir birliği bulunmaktadır (Knechel, 2016: 220).

Denetim kalitesi ve finansal raporlama kalitesi o kadar iç içe geçen bir kavramdır ki birbirlerini etkilememesi neredeyse imkansızdır. Denetim kalitesi ile finansal raporlama kalitesi arasındaki ilişkiyi sorgulayan çalışmalar incelendiğinde ise finansal raporlama kalitesinin çoğunlukla "ihtiyari tahakkuklar" (kar yönetimi uygulamaları) ya da "muhafazakar muhasebe uygulamaları" kapsamında ele alındığını söylemek mümkündür (Knechel, 2013: 350). Yapılan çalışmalar genel olarak ihtiyari tahakkuklar ya da kar arttırıcı yönde kullanılan ihtiyari tahakkuklar ile denetim kalitesi (Francis vd., 1999: 30, Kim vd., 2003), denetçi uzmanlığı (Krishnan 2003b: 13), denetçinin çalışma süresi (Myers vd., 2003) arasında negatif ilişki raporlamıştır. Muhasebe bilgi kalitesinin bir ölçütü olarak ele alınan muhafazakar muhasebe uygulamaları ile ise denetçi ihtilafları arasında negatif (DeFond vd., 2012: 280), denetçi firma büyüklüğü, denetçi uzmanlığı ya da denetçi çalışma süresi arasında pozitif (Basu vd., 2000, Jenkins ve Velury, 2008: 128) ilişki raporlayan çalışmalar mevcuttur. Firmaları kar yönetimine iten neden ve motive edici faktörler çerçevesinde yöneticilerin finansal tablo hazırlama sürecindeki faydacı ihtiyari davranışları bağımsız denetim sayesinde biraz olsun sınırlanmaktadır (Chen vd., 2011). Bu bağlamda denetim kalitesinin kar yönetimi davranışı üzerindeki etkisi kar yönetimi davranışı ekseninde değişiklik gösterse bile çoğu durumda denetim kalitesinin finansal raporlama kalitesi üzerindeki anlamlı pozitif etkisinden bahsetmek yanlış olmaz (Frankel vd., 2002: 80, Charles vd., 2010: 25, Chen vd., 2011).

Denetim kalitesinin ölçümünde hangi aracı değişkenlerinin kullanılacağı konusunda bir fikir birliği olmamakla beraber literatür çoğunlukla denetçi büyüklüğü (DeAngelo, 1981: 192, Dopuch ve Simunic, 1982, Craswell vd., 1995: 302, Krishnan, 2003a: 110), denetçi uzmanlığ 1 (Bedard ve Biggs, 1991: 85, Maletta ve Wright, 1996: 82, Krishnan, 2003b: 7, Krishnan, 2005: 23, Francis vd., 2005) denetim ile ilişkili olan ve olmayan ücretler (Kinney ve Libby, 2002: 108, Ashbough vd., 2003: 613, Krishnan vd., 2008: 67) üzerine yoğunlaşmaktadır.

Yapılan çalışmalar özellikle denetim firması büyüklüğünü, bu firmaların gerek sahip oldukları kaynaklar, eğitim programları, sahip oldukları marka değeri ve ünü koruma çabaları gerek sahip oldukları personelin deneyim ve kalitesi nedeniyle denetim kalitesi için önemli bir ölçüt olarak görmekte ve finansal raporlama kalitesi üzerinde olumlu etkisi olduğunu savunmaktadır. DeAngelo (1981) denetim kalitesinin ölçümünde denetim şirketinin büyüklüğünü (Büyük Dört denetim şirketinden biri olup olmama durumu) esas almıştır. Buna göre Büyük Dört denetim şirketi olarak anılan şirketler marka imajlarından ve sektördeki deneyimlerinden dolayı, gerek usulsüzlükleri tespit etmede olan başarıları gerek tespit edilen usulsüzlükleri raporlama konusundaki bağımsızlıkları nedeniyle denetim kalitesi yüksek şirketlerdir. Bu denetim firmaların yüksek denetim kalitesiyle ilişkilendirilmelerinin ardında sadece kaynaklarının çokluğu değil, var olan kaynaklarını personel eğitimine, emsal değerlendirmelere ve bilgi teknolojileri yatırımlarına aktarmaları da yer almaktadır (Dopuch ve Simunic, 1982, Craswell vd., 1995: 310). Bu çerçevede literatürde denetim kalitesi ile denetim şirketi büyüklügü arasında anlamlı pozitif ilişki raporlayan birçok çalışma yer almaktadır (Watts ve Zimmerman, 1981, Teoh ve Wong, 1993: 347, DeFond vd., 1997: 117, 
Francis vd., 1999: 18, Krishnan, 2003: 110, Basu vd., 2000, Lin ve Hwang, 2010: 57, DeFond ve Zang, 2013, Knechel vd., 2016: 215).

Denetçinin sektörel uzmanlığı ise denetim kalitesi ölçümünde ele alınan bir diğer ölçüttür. Sektörlerin kendilerine has dinamikleri bulunmakta olup, farklı sektörlerde faaliyet gösteren firmaların denetim süreçleri ve bu süreçte karşılaşılması olası hata, hile ve raporlama davranışları da farklılaşmaktadır (Maletta ve Wright, 1996: 85). Bu çerçevede belirli bir sektörde uzman olan denetçinin, o sektörün dinamiklerine daha hakim olması, bu şekilde yapılması gereken ya da yapılmaması gereken faaliyetler kadar neyin nasıl yapılması gerektiği konusunda da bilgi ve deneyim sahibi olarak; yanlış, hata ve hileli muhasebeleştirme uygulamalarını daha kolay tespit etmesi ve daha kaliteli bir denetim hizmeti sunmas1 beklenmektedir (Bedard ve Biggs, 1991: 79, Wright ve Wright, 1997: 275, Balsam vd., 2003: 74 , Elder vd., 2015: 76, Dunn ve Mayhew, 2004: 37, Hoitash vd., 2007: 764, Reichelt ve Wang, 2010: 647, Burnett vd., 2012: 1863). GAO (General Accounting Office) raporuna göre (2003) de örneğin Büyük Dört denetim şirketinden KPMG ve PwC finansal sektör alanında uzmanlaşmış denetim şirketleridir. GAO'nun denetçi uzmanlığı konusunda ileri sürdüğü tespit 2003 yılına olmakla birlikte denetçi uzmanlığına ilişkin çalışmalarda (Kanagaretnam vd., 2009, Bratten vd., 2017: 5) hala geçerliliğini korumaktadır. Krishnan (2003: 120) belli sektörlerde uzmanlaşmış denetçiler tarafindan finansal tabloları denetlenen firmalarda kar yönetimi göstergesi olarak kabul edilen ihtiyari tahakkukların daha düşük seviyede gözlemlendiğini raporlamıştır.

Lim ve Tan (2008) sektörel anlamda uzmanlaşmış denetçilerin imaj kaybı ya da dava risklerine karşı daha temkinli olduklarını ve bu durumun da denetim kalitesini arttırdığını gözlemlemişlerdir. Benzer şekilde Balsam vd. (2003) de sektörel uzmanlaşma sağlayan denetim firmaları ile ortaya çıkarılan muhasebeleştirme manipülasyonları arasında negatif ilişki bulmuşlardır

Lin ve Hwang (2010) denetim kalitesinin ölçümünde aracı değişken olarak denetçi büyüklüğü, sektörel uzmanlaşma, denetçi ücretleri ve denetim süresi gibi birçok faktörü dikkate almışlardır ve sadece Büyük Dört denetim firmasından olup olmama durumu (denetçi büyüklüğü) ve denetçinin sektörel anlamda uzmanlaşmasının finansal raporlama kalitesini arttırdığııı (kar yönetimini azalttığını) raporlamışlardır.

Kanagaretnam vd. (2010) 29 ülkede faaliyet gösteren bankalar üzerine yaptıkları çalışmada, yüksek itibarlı denetim şirketleri tarafından denetlenen bankaların kar yönetimi davranışlarını gözlemlemişlerdir. Yüksek itibarlı denetim şirketi olma durumunu ise "Büyük 5" denetim şirketi arasında olup olmama durumu ile ilişkilendirmişlerdir. Elde edilen sonuçlara göre denetçi tipi (Büyük 5 denetim şirketinden biri olup olmama) ve denetçi uzmanlığının kar yönetimi uygulamaları üzerinde kısıtlayıcı etkisi olduğu raporlanmıştır. Ancak, bu iki denetim kalitesi göstergesi aynı anda aynı model içinde test edildiğinde, sadece sektörel uzmanlık anlamlı olmaktadır.

Chen vd. (2011) denetim kalitesini denetim şirketi büyüklüğü olarak ölçmüşler ve uluslararası seviyede Büyük Dört denetim şirketinin de içinde yer aldığı Büyük 8 denetim şirketi porföyü oluşturmuşlardır. Elde ettikleri sonuçlara göre denetim şirketi büyüklüğü, hileli muhasebeleştirme uygulamalarını azaltmakta ve finansal raporlama kalitesini arttırmaktadır. 
DeBoskey ve Jiang (2012), 2002-2006 dönemi için ABD (Amerika Birleşik Devletleri) bankalarının finansal raporlama kalitesi ile denetim kalitesi arasındaki ilişkiyi analiz etmişlerdir. Elde edilen sonuçlar ABD bankaları için karın istikrarlı gösterilmesi hipotezini desteklemekle beraber, özellikle denetçinin sektörel uzmanlığının kar yönetimi uygulamalarını azalttığını göstermektedir.

Magnis ve Iatridis (2017), ABD, İngiltere, Fransa ve Almanya'da faaliyet gösteren bankalar için yaptıkları analizde, denetim kalitesinin kar yönetimi ve sermaye yönetimi üzerindeki olası etkilerini sorgulamışlardır. Elde edilen sonuçlara göre denetçi büyüklüğü (Büyük Dört) ve denetçinin sektörel uzmanlığı kar yönetimi davranışını baskılamaktadır. Diğer taraftan, denetçinin sektörel uzmanlığının özellikle zarardan kaçınma şeklindeki kar yönetimi uygulamalarında, denetçi büyüklüğünün ise geçmiş dönem kar rakamını yakalama ya da üzerine çıkma güdülü kar yönetimi uygulamalarında kısıtlayıcı etkisi olduğu vurgulanmıştır.

Maijoor ve Vanstraelen (2006), İngiltere, Fransa ve Almanya üzerine kurguladıkları çalışmada uluslararası Büyük Dört denetim firmasından hizmet alan firmalarda kar yönetimi uygulamalarına daha düşük seviyede rastlamışlardır. Ancak ülke bazındaki rejim ve uygulama farklılıklarından dolayı denetim kalitesi ile finansal raporlama kalitesi arasındaki ilişkinin yönü ve büyüklüğü değişkenlik göstermektedir. Ülkelerarası farklılaşmaya örnek olarak Habbash ve Alghamdi (2017) de denetim kalitesi ile muhasebeleştirme manipülasyonları arasında pozitif ilişki raporlamış, gelişmiş ülkelerde geçerli olan model uygulamalarının Orta Doğu'da ya da az gelişmiş ülkelerde geçerliliğini sorgulamışlardır.

Ayrıca literatürde denetçi ücretleri ile denetim kalitesi arasındaki ilişkiyi sorgulayan çalışmalar da mevcuttur. Bu alanda ise birbiri ile çelişen sonuçlara rastlamak mümkündür. Öyle ki bazı çalışmalar denetim sektörünün çok sıkı düzenlemeler ve gözetime maruz kaldığını bu yüzden de yüksek denetim ücretlerinin denetim sürecinde harcanan emek ile ilişkili olduğunu ve denetim kalitesini arttırdığını savunmaktadır (Lowensohn vd., 2007: 706, Srinidhi ve Gul, 2007: 596, Venkataraman vd., 2008: 1346, Francis ve Yu, 2009: 1522, Kanagaretnam vd., 2011: 162). Bu çerçevede denetçi ücreti; bağımsız denetçinin gösterdiği çabanın bir göstergesi olarak dikkate alınmaktadır. Diğer taraftan yüksek denetçi ücretlerinin denetçi bağımsızlığını zedelediği ve bu yüzden denetim kalitesini düşürdüğü yönünde bulgular raporlayan çalışmalar da bulunmaktadır (Plitch, 2003, Brandon vd., 2004, Lim ve Tan, 2008).

\section{ARAŞTIRMANIN YÖNTEMİ VE AMPİRIK MODEL TASARIMI}

Bu çalışma denetim kalitesi ile finansal raporlama kalitesi arasındaki ilişkinin finansal sektör çerçevesinde test edilmesine yöneliktir. Literatür taramasında ayrıntılı bir şekilde ele alındığ1 gibi denetim kalitesinin ölçümünde denetçi şirketin büyüklüğünün ölçümünde sıklıkla kullanılan denetim firmasının "Büyük Dört" denetim şirketi olarak adlandırılan dört şirketten (Deloitte, PriceWaterHouseCoopers, ErnstYoung ve KPMG) biri olup olmaması ve denetçi şirketin sektörel açıdan uzmanlaşıp uzmanlaşmaması aracı değişkenler olarak ele alınmıştır. Sektörel açıdan uzmanlaşma durumunun tespitinde ise GAO raporu baz alınarak denetim şirketinin PwC ya da KPMG şirketlerinden biri olup olmamasına dikkat edilmiştir. Finansal raporlama kalitesinin ölçümünde ise finansal sektör kar yönetimi uygulamalarından "karın istikrarlı gösterilmesi" hipotezi kapsamında analizler yapılmıştır. Kar yönetimi uygulamalarının ele alındığı literatür çerçevesinde bu alana yön veren araştırmacılardan 
Beatty vd. (1995), Ahmed vd. (1999), Kanagaretnam vd. (2003, 2010) tarafindan da doğrulandığı üzere banka yöneticilerinin banka finansal tablo kalemleri içinde en büyük tahakkuk kalemi olan "beklenen zarar karşılıkları" aracılığıyla kar yönetimi yaptıkları (karı istikrarlı hale getirme şeklinde) raporlanmıştır. Yapılan bu çalışma ise denetim kalitesinin kar yönetimi uygulamaları üzerindeki kısıtlayıcı etkisini sorgulamaktadır.

Finansal sektör kar yönetimi çalışmalarıyla uyumlu olarak kar yönetiminin tespitinde beklenen zarar karşılıkları giderleri ile beklenen zarar karşılıkları öncesi vergi sonrası kar arasındaki ilişki test edilmiştir (Wahlen, 1994: 365, Beatty vd., 1995: 231, Ahmed vd., 1999: 2, Kanagaretnam vd., 2004: 843, Anandarajan vd., 2005: 55, Fonseca ve Gonzalez, 2008: 218). Finansal raporlama kalitesi ile denetim kalitesi arasındaki ilişkinin tespiti için ise Kanagaretnam vd. (2010) tarafindan test edilen modelden hareket edilmiştir. Bu çerçevede kar yönetimi uygulamaları ile denetim kalitesi arasındaki ilişki aşağıda yer alan ampirik model kapsamında panel veri analizi aracılığıyla test edilmiştir. İlk aşamada beklenen zarar karşılıkları giderleri tahmin edilmiş ve modelin hata teriminden kar yönetimi amacıyla kullanıldığı literatür tarafindan desteklenen "ihtiyari beklenen zarar karşılıkları giderleri” elde edilmiştir. Beklenen zarar karşılıkları giderlerinin tahmin edildiği model şu şekildedir (Kanagaretnam vd.,2010):

$$
\mathrm{LLP}=\alpha_{0}+\alpha_{1} \mathrm{BLLA}+\alpha_{2} \mathrm{LCO}+\alpha_{3} \Delta \mathrm{TL}+\alpha_{4} \mathrm{TL}+\alpha_{5} \mathrm{NPL}+(\text { YEAR CONTROLS })+
$$
(FIRM CONTROLS) $+\varepsilon$

Finansal raporlama kalitesi ile denetim kalitesi arasındaki ilişkinin test edilmesinde kullanılan model tasarımı ise şu şekildedir (Kanagaretnam vd.,2010):

DLLP $=\beta_{0}+\beta_{1}$ BIG $4+\beta_{2}$ AUDITSPEC $+\beta_{3}$ TA $+\beta_{4}$ ASSETGROWTH $+\beta_{5}$ PRIORLLP $+\beta_{6}$ EBLLP $+\beta_{7}$ REGCAP $+($ YEAR CONTROLS $)+($ FIRM CONTROLS $)+\varepsilon$

Değişken tanımları ve analizden beklenen ilişki yönleri aşağıda verilmiş̧ir:

$\begin{array}{lc}\text { Değişkenler } & \begin{array}{c}\text { Regresyon Analizinden } \\ \text { Beklenen İlişki Yönü }\end{array} \\ \text { LLP = Beklenen Zarar Karşılıkları Giderleri1 } \\ \text { DLLP = Beklenen Zarar Karşılıkları Giderleri İhtiyari Kısmı } \\ \text { BLLA = Dönem Başı Beklenen Zarar Karşılıkları² } \\ \text { LCO = Aktiften Silinen Krediler } & + \\ \begin{array}{l}\text { TTL = Toplam Kredilerdeki Değişim } \\ \text { TL = Toplam Krediler }\end{array} & + \\ \text { NPL = Takipteki Krediler (Donuk Alacaklar) } & + \\ \text { Big4 = Denetim “Büyük4” denetim firması tarafından yapılıyorsa “1”, } & + \\ \text { diğer durumlar “0” } & - \\ \begin{array}{l}\text { AUDITSPEC = Denetim “PwC ya da KPMG” denetim firmalarından } \\ \text { biri tarafından yapılıyorsa “1”, diğer durumlar “0” }\end{array} & -\end{array}$

\footnotetext{
${ }^{1}$ 2003-2017 dönemi için ilgili hesap finansal tablolarda "Kredi ve Diğer Alacaklar Değer Düşüş Karşllıkları”, 2018 itibariyle ise "Beklenen Zarar Karşılıkları Giderleri" olarak yer almaktadır. Uluslararası literatürde ise "Loan Loss Provision" olarak karşımıza çıkar.

2 2003-2017 dönemi için ilgili hesap finansal tablolarda "Özel Karşılıklar”, 2018 itibariyle ise "Beklenen Zarar Karş1lıkları" olarak yer almaktadır. Uluslararası literatürde ise "Loan Loss Allowance”" olarak karşımıza çıkar.
} 


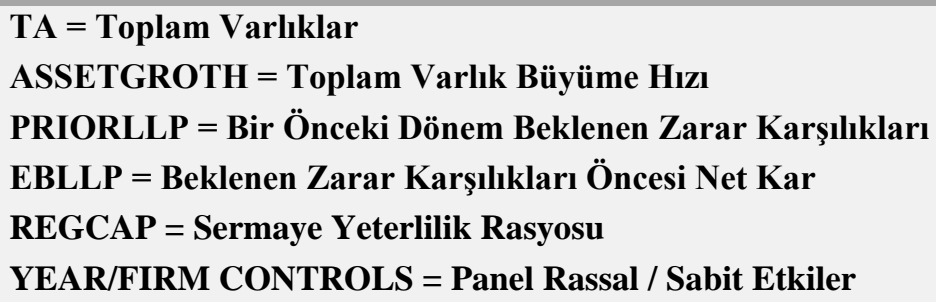

Analizler panel veri teknikleri kullanılarak yapılmıştır. Panel veri analizi, zaman boyutuna ait kesit verileri kullanarak ekonomik ilişkilerin tahmin edilmesini içeren bir ekonomik yöntemdir (Gujarati, 2003). Diğer bir ifadeyle panel veri analizi verileri yatay kesit ve zaman serisi bazında birleştirerek bir analiz kurgular. Bu çerçevede panel veri ile yapılan analizler yatay kesit ve zaman serilerinin özelliklerini de içerdiği için yatay kesit ve zaman serisi analizlerine oranla daha çok ve istatistiki anlamda daha sağlam bilgi yansıtır (Baltagi, 2008: 228).

Çalışma kapsamında analiz edilen gözlem büyüklüğü Türk bankacılık sektörü ile sınırlı olduğu için nispeten azdır. Ayrıca örneklem tüm bankacılık sektörünü içerdiği için heterojen bir yapı göstermektedir (kamu/özel sermayeli bankalar, yerli/yabancı sermayeli bankalar, vb.). Bahsi geçen kısıtların sonuçlar üzerindeki olası olumsuz etkilerini azaltması açısından analizlerin yapılmasında panel regresyon yöntemi kullanılmıştır. Diğer taraftan değişkenlerin hepsi dönem başı toplam aktifler ile normalize edilmiş ve çalışmanın temel modelinde bağımlı değişken olarak "beklenen zarar karşılıkları"nın tahmin edilerek ilgili modelin hata terimlerinin kullanılması dolayısıyla karşılaşılabilecek otokorelasyon problemleri nedeniyle gerekli hata düzeltmeleri yapılmıştır.

\subsection{Araştırma Örneklemi ve Hipotezler}

Bu çalışma kapsamında Türk bankacılık sektörünün kar yönetimi davranışı üzerinde bağımsız denetim süreci kalitesinin etkisi incelenmiştir. Çalışma kapsamında yapılan bütün analizler panel veri analiz teknikleri kullanılarak "Eviews 8" istatistik ve ekonometri paket programı aracılığıyla yapılmıştır. Bu çerçevede çalışmada Türk Bankacılık sistemi içerisinde 2003-2018 yılları arasında faaliyette bulunmuş 22 bankanın finansal tabloları incelenmiş ve örneklem seti oluşturulmuştur. Farklı faaliyet ve finansal raporlama süreçlerinden dolayı kalkınma ve yatırım bankalarının dahil edilmediği analizlerde nihai örneklem ise 312 bankay1lı veridir.

Literatür taraması çerçevesinde ortaya konulan argümanlar kapsamında kurulan alternatif hipotezler şu şekildedir.

$\mathrm{H}_{1}=$ Beklenen zarar karşılıklarının ihtiyari kısmı ile karşılık öncesi net kar arasında anlamlı bir ilişki vardır.

$\mathrm{H}_{2}=$ Denetim kalitesi ile finansal raporlama kalitesi arasında anlamlı bir ilişki vardır.

i) $\mathrm{H}_{2 \mathrm{~A}}=$ Denetim firması büyüklüğ̈̈ ile finansal raporlama kalitesi arasında anlamlı bir iliş̧ki vardir. 
ii) $\mathrm{H}_{2 \mathrm{~B}}=$ Denetim firmasının finansal sektörde uzmanlaşmış bir denetim firması olması ile finansal raporlama kalitesi arasında anlamlı bir ilişki vardır.

\subsection{Veri Analizi ve Araştırmanın Bulguları}

Çalışma kapsamında yapılan analizlerde kullanılan değişkenlere ilişkin özet tanımlayıcı istatistiki bilgiler Tablo 1 Panel A'da verilmiştir. Panel B'de ise değişkenler arası Pearson korelasyon katsayıları yer almaktadır. Panel A'da yer alan değişkenlerin ortalama değerleri incelendiğinde beklenen zarar karşılıklarının (loan loss allowance) büyüklük olarak vergi ve karş1lık öncesi kar değerinin yaklaşık \%69'u ve kredi ve diğer alacaklar değer düşüklüğü karşılığının (beklenen zarar karşılıkları) ise vergi ve karşılık öncesi kar değerinin \%40'1 kadar olduğu gözlemlenmektedir. Dolayısıyla bilanço ve gelir tablosunda yer alan her iki karşılık tutarının da net kar ile kıyaslandığında önemli boyutta olduğu söylenebilir. Karşılıklar ile toplam varlıklar arasındaki ilişkiye bakıldığında ise beklenen zarar karşılıkları ortalama toplam varlıkların \% 2'si iken kredi ve diğer alacaklar değer düşüklügüu karşılıkları ise toplam ortalama aktif büyüklüğünün \%1'i kadardır.

Diğer taraftan Panel A incelendiğinde, ortalama verilere göre, kredi portföyünün kalitesine ilişkin olarak, toplam kredilerinin \%3'ünü takipteki krediler, \%0,33'ünü ise aktiften silinen krediler oluşturmaktadır. Beklenen zarar karşılıkları toplam kredilerin \%2'sini oluştururken gelir tablosunda yer alan "beklenen zarar karşılıkları" ise toplam kredilerin \%1'ine denk gelen bir büyüklüğe sahiptir. Tablo 1 Panel B'de ise değişkenler arası ilişkileri gösteren Pearson korelasyon analizi değerleri raporlanmıştır. Yapılan analizlerde elde edilen sonuçların istatistiksel açıdan yanlı olmaması, doğru ve güvenilir olmasını sağlamak için bağımsız değişkenler arasında görülebilecek çoklu bağlantı sorunun tespiti için Pearson korelasyon tablosunda raporlanan korelasyon değerlerinin doğru bir şekilde yorumlanması gerekmektedir. Kar yönetimi literatürü incelendiğinde ise kar yönetimi aracılığıyla karı istikrarlı gösteren firmalarda beklenen zarar karşılıkları ya da kredi ve diğer alacaklar değer düşüklüğü karşılıkları hesapları ile vergi ve karşılık öncesi kar arasında anlamlı pozitif ilişki saptanmıştır. Pearson korelasyon değerlerine göre beklenen zarar karşılıkları giderlerinin ihtiyari kısmı (DLLP) ile vergi ve karşılık öncesi kar arasında \%5 istatistiksel anlamlılık düzeyinde pozitif bir korelasyon $(0,08)$ bulunmaktadır. Denetim kalitesi kapsamında ise ihtiyari karş1lıklar ile denetim firması büyüklüğü ve denetçinin finansal sektör uzmanlığı arasında negatif korelasyon saptanmıştır.

Tablo 1. Tanımlayıcı İstatistikler

Panel A. Değişkenlere Ait Tanımlayıcı İstatistikler

\begin{tabular}{|l|l|l|l|l|l|}
\hline Değişkenler & Ortalama & Ortanca & Mak. & Min. & Std. Sapma \\
\hline LLP & 644547.1 & 189734.0 & 7121703. & 0.00 & 7121703. \\
\hline DLLP & -0.000108 & -0.000396 & 0.040839 & -0.024377 & 0.005906 \\
\hline LLA & 1124630. & 342775.0 & 13692652 & 0.00 & 1877593. \\
\hline LCO & 149324.2 & 2359.000 & 4583196. & 0.00 & 389774.8 \\
\hline TL & 45308942 & 12183535 & $4.80 \mathrm{E}+08$ & 2329.000 & 77629846 \\
\hline NPL & 1317629. & 476025.0 & 12379857 & 0.00 & 1999719. \\
\hline Big4 & 0.973770 & 1.00 & 1.00 & 0.00 & 0.160080 \\
\hline
\end{tabular}




\begin{tabular}{|l|l|l|l|l|l|}
\hline AUDITSPEC & 0.521311 & 1.00 & 1.00 & 0.00 & 0.500367 \\
\hline TA & 64131544 & 21204774 & $5.37 \mathrm{E}+08$ & 25564.00 & 93738257 \\
\hline EBLLP & 1630885. & 433513.0 & 13112759 & -1416668. & 2381206. \\
\hline REGCAP & 22.50263 & 16.80000 & 148.2000 & 7.239254 & 16.99901 \\
\hline Gözlem Sayısı & $\mathbf{3 0 5}$ & $\mathbf{3 0 5}$ & $\mathbf{3 0 5}$ & $\mathbf{3 0 5}$ & $\mathbf{3 0 5}$ \\
\hline
\end{tabular}

Panel B. Pearson Korelasyon Tablosu

\begin{tabular}{|c|c|c|c|c|c|c|c|}
\hline \multicolumn{8}{|l|}{ Korelasyon Katsayısı } \\
\hline Olasılık Değeri & BIG_4 & $\mathrm{C}$ & LOG(TA) & LLP_A & EBLLP_A & REG_CAP & DLLP \\
\hline BIG_4 & 1.00 & & & & & & \\
\hline & ----- & & & & & & \\
\hline \multirow[t]{2}{*}{ KPMG_PWC } & 0.21 & 1.00 & & & & & \\
\hline & $0.00^{* * *}$ & ----- & & & & & \\
\hline \multirow[t]{2}{*}{ LOG(TA) } & 0.08 & -0.01 & 1.00 & & & & \\
\hline & 0.16 & 0.89 & ----- & & & & \\
\hline \multirow[t]{2}{*}{ LLP_A } & -0.01 & -0.04 & 0.12 & 1.00 & & & \\
\hline & 0.88 & 0.47 & $0.03 * *$ & ----- & & & \\
\hline \multirow[t]{2}{*}{ EBLLP_A } & -0.24 & -0.01 & 0.01 & 0.16 & 1.00 & & \\
\hline & $0.00^{* * *}$ & 0.89 & 0.87 & $0.01^{* * *}$ & ----- & & \\
\hline \multirow[t]{2}{*}{ REG_CAP } & -0.20 & 0.04 & -0.57 & -0.16 & 0.34 & 1.00 & \\
\hline & $0.00^{* * *}$ & 0.45 & $0.00 * * *$ & $0.00 * * *$ & $0.00^{* * *}$ & ----- & \\
\hline \multirow[t]{2}{*}{ DLLP } & -0.01 & -0.01 & -0.01 & 0.60 & 0.08 & -0.10 & 1.00 \\
\hline & $0.03^{* *}$ & $0.07 *$ & 0.91 & $0.00^{* * *}$ & $0.02 * *$ & $0.08 *$ & ---- \\
\hline
\end{tabular}

*. **, ***; srrasıyla $\% 10, \% 5$ ve $\% 1$ istatistiksel anlamlılık düzeylerini temsil etmektedir. 
Tablo 2. Regresyon Analizi Sonuçları

\begin{tabular}{|c|c|c|c|c|c|c|c|c|c|}
\hline \multirow[b]{2}{*}{ Değişkenler } & \multirow[b]{2}{*}{$\begin{array}{l}\text { Tahmin Edilen } \\
\text { İlişki }\end{array}$} & \multicolumn{2}{|c|}{ M1 } & \multicolumn{2}{|r|}{ M2 } & \multicolumn{2}{|r|}{ M3 } & \multicolumn{2}{|r|}{ M4 } \\
\hline & & Katsayı & $\begin{array}{l}\text { P değeri } \\
\text { (t değeri) }\end{array}$ & Katsayı & $\begin{array}{l}\text { P değeri } \\
\text { (t değeri) }\end{array}$ & Katsayı & $\begin{array}{l}\text { P değeri } \\
\text { (t değeri) }\end{array}$ & Katsayı & $\begin{array}{l}\text { P değeri } \\
\text { (t değeri) }\end{array}$ \\
\hline \multicolumn{10}{|c|}{ Bağımlı Değişken = DLLP } \\
\hline Kesim Katsayısı & & -0.0223 & $\begin{array}{l}0.05^{* *} \\
(-1,96)\end{array}$ & -0.0300 & $\begin{array}{l}0.01 * * * \\
(-2,336)\end{array}$ & -0.032 & $\begin{array}{l}0.01 * * * \\
(-2,48)\end{array}$ & -0.032 & $\begin{array}{l}0.01 * * * \\
(-2.51)\end{array}$ \\
\hline Big4 & - & - & - & -0.0023 & $\begin{array}{l}0.05^{* *} \\
(-1,96)\end{array}$ & - & - & -0.002 & $\begin{array}{l}0.11 \\
(-1.59)\end{array}$ \\
\hline AUDITSPEC & - & --- & -- & - & - & -0.001 & $\begin{array}{l}0.05 * * \\
(-1,96)\end{array}$ & -0.001 & $\begin{array}{l}0.05 * * \\
(-1.89)\end{array}$ \\
\hline $\operatorname{Ln}(\mathrm{TA})$ & + & 0.0010 & $\begin{array}{l}0.10^{*} \\
(1,52)\end{array}$ & 0.00166 & $\begin{array}{l}0.03^{* *} \\
(2.15)\end{array}$ & 0.0016 & $\begin{array}{l}0.03 * * \\
(2,14)\end{array}$ & 0.0018 & $\begin{array}{l}0.02 * * \\
(2.33)\end{array}$ \\
\hline PRIORLLP & + & 0.666 & $\begin{array}{l}0.00 * * * \\
(20,78)\end{array}$ & 0.68030 & $\begin{array}{l}0.00^{* * *} \\
(20,98)\end{array}$ & 0.6816 & $\begin{array}{l}0.00^{* * *} \\
(21,03)\end{array}$ & 0.6845 & $\begin{array}{l}0.00 * * * \\
(21.15)\end{array}$ \\
\hline EBLLP & + & 0.035 & $\begin{array}{l}0.01 * * * \\
(2,34)\end{array}$ & 0.0299 & $\begin{array}{l}0.05 * * \\
(1,96)\end{array}$ & 0.0318 & $\begin{array}{l}0.05^{* *} \\
(1,96)\end{array}$ & 0.0289 & $\begin{array}{l}0.08^{*} \\
(1.76)\end{array}$ \\
\hline REGCAP & - & $05^{-9.57 \mathrm{E}-}$ & $\begin{array}{l}0.00 * * * \\
(-4,53)\end{array}$ & -0.001 & $\begin{array}{l}0.00 * * * \\
(-5,23)\end{array}$ & -0.001 & $\begin{array}{l}0.00 * * * \\
(-5,18)\end{array}$ & -0.001 & $\begin{array}{l}0.00 * * * \\
(-5.35)\end{array}$ \\
\hline Düzeltilmiş $\mathbf{R}^{2}$ & \multicolumn{3}{|c|}{$\begin{array}{c}0,57 \\
(0,00 * * *)\end{array}$} & \multicolumn{2}{|c|}{$\begin{array}{c}0,59 \\
\left(0,00^{* * *}\right)\end{array}$} & \multicolumn{2}{|c|}{$\begin{array}{c}0,59 \\
(0,00 * * *)\end{array}$} & \multicolumn{2}{|c|}{$\begin{array}{c}0,59 \\
(0,00 * * *)\end{array}$} \\
\hline Gözlem Sayısı & \multicolumn{3}{|c|}{330} & \multicolumn{2}{|c|}{312} & \multicolumn{2}{|c|}{312} & \multicolumn{2}{|r|}{312} \\
\hline $\begin{array}{l}\text { YEAR/FIRM } \\
\text { CONTROLS }\end{array}$ & \multicolumn{3}{|c|}{ Sabit Etkiler } & \multicolumn{2}{|c|}{ Sabit Etkiler } & \multicolumn{2}{|c|}{ Sabit Etkiler } & \multicolumn{2}{|c|}{ Sabit Etkiler } \\
\hline
\end{tabular}

*. **, ***; sirasıyla $\% 10, \% 5$ ve $\% 1$ istatistiksel anlamlılık düzeylerini temsil etmektedir. 
Tablo 2'de ise panel regresyon analizinin sonuçları yer almaktadır. Öncelikle $\mathrm{H}_{1}$ hipotezi karın istikrarlı gösterilmesi hipotezinin test edilmesine yöneliktir (M1). Denetim kalitesine yönelik herhangi bir değişkenin eklenmediği ilk analizde elde edilen sonuçlar Türk bankacılık sektörünü oluşturan bankaların ihtiyari tahakkuklar aracılığıyla kar yönetimi yaptıkları şeklindedir $\left(\mathrm{R}^{2}=0.57, \mathrm{p}\right.$ değeri $\left.=0.00\right)$. Bu çerçevede, finansal raporlama kalitesi kapsamında, beklenen zarar karşılıkları giderlerinin ihtiyari kısmı ile karşılık öncesi net kar arasında istatistiksel açıdan anlamlı ve pozitif ilişki (katsayı: 0.035, p değeri=0.01) saptanmıştır. Bu sonuca dayanarak incelenen 2003-2018 dönemi için Türkiye'de faaliyet gösteren bankalarda karın istikrarlı gösterilmesi şeklinde kar yönetimi yapıldığı söylenebilir. Karın istikrarlı gösterilmesi hipotezi $\left(\mathrm{H}_{1}\right)$ bu sonuç çerçevesinde reddedilememiştir. Kar yönetiminin tespit edildiği ilk modelde ihtiyari tahakkukların iki aşamalı model çerçevesinde toplam tahakkuklardan ayrıştırılarak analiz edilmesi ile bankaların normal faaliyet akışı çerçevesinde ayırdıkları karşılıkların tamamen kar yönetimi aracı olarak kullanıldığ yanlış bir çıkarımın yapılmasının da önüne geçilmiştir.

$\mathrm{Bu}$ çalışmanın temel araştırma sorusu ise denetim kalitesinin finansal raporlama kalitesi üzerindeki etkisi, bir diğer ifadeyle kısıtlayıcı bir etkisi olup olmamasına ilişkindir $\left(\mathrm{H}_{2}\right)$. Denetim kalitesi ile finansal raporlama kalitesi arasındaki ilişkinin tespitinde ise literatürle aynı prosedür izlenerek, önce denetim kalitesinin ölçümünde kullanılan değişkenlerin finansal raporlama kalitesi üzerindeki etkileri tek tek (M2 ve M3), sonrasında denetim kalitesi aracı değişkeni olarak modele dahil edilen tüm değişkenler toplu olarak (M4) analiz edilmiştir.

Çalışma kapsamında denetim kalitesinin ölçümünde kullanılan aracı değişkenlerden biri denetim firmasının büyüklüğüdür $\left(\mathrm{H}_{2 \mathrm{~A}}\right)$. Denetim firmasının büyüklüğünün tespitinde ise literatürle uyumlu olarak, bankanın finansal tablolarının denetimini yapan denetçi firmanın "Büyük Dört" denetim şirketinden biri olup olmadığı dikkate alınmıştır (Huang ve Li, 2013: 150). Elde edilen sonuçlara göre (M2) "Büyük Dört" denetim şirketi tarafından denetlenen bankaların beklenen kredi zararlarının ihtiyari kısmı diğerlerine göre anlamlı bir şekilde ( $\mathrm{p}$ : $0,05)$ daha düşüktür $(-0,0023)$. Dolayısıyla denetim firması büyüklüğü ile finansal raporlama kalitesi arasında anlamlı ve pozitif bir ilişski gözlemlenmiş ve bu nedenle $\mathrm{H}_{2 \mathrm{~A}}$ reddedilememiştir. Bu çerçevede elde edilen sonuçlar literatürle (Kanagaretnam vd., 2010, DeBoskey ve Jiang, 2012, Magnis ve Iatridis, 2017) uyumludur.

Diğer taraftan denetim kalitesine ilişkin herhangi bir değişkenin eklenmediği "M1" modeli ile kıyaslandığında kar yönetimi yapıldığının göstergesi olarak dikkate alınan ihtiyari tahakkuklar ile tahakkuk öncesi net kar arasındaki ilişkinin zayıfladığı gözlemlenmiştir. Bu kapsamda "beklenen zarar karşılıkları giderleri" ile "beklenen zarar karşılıkları öncesi net kar" arasındaki ilişkinin istatistiksel anlamlılı̆̆ $\% 1$ seviyesinden $\% 5$ seviyesine gerilemiş, aynı zamanda iki değişken arasındaki ilişkinin katsayısı da 0.035 'ten 0.029 'a düşmüştür. Dolayısıyla denetçi firmanın büyüklüğünün (Büyük Dört denetim şirketinden birinden hizmet alınıp alınmaması), kar yönetimi uygulamasını ortadan kaldırmamakla beraber, finansal raporlama kalitesi üzerinde göreceli olumlu etkisinin olduğu söylenebilir. Bu çerçevede $\mathrm{H}_{2 \mathrm{~A}}$ reddedilememiştir.

Denetim kalitesinin tespitinde kullanılan bir diğer aracı değişken ise denetim firmasının finansal sektör bazında uzmanlaşıp uzmanlaşmadığı, daha genel bir ifadeyle 
denetçi uzmanlığına ilişkindir (Kanagaretnam vd., 2010: 2321, DeBoskey ve Jiang, 2012: 613, Magnis ve Iatridis, 2017: 338). GAO raporundan yola çıkarak PwC ve KPMG şirketleri finansal sektörde faaliyet gösteren şirketlerin bağımsız denetiminde uzmanlaşmış şirketler olarak dikkate alınmış ve bu argümanla modele dahil edilmişlerdir. Elde edilen sonuçlara göre (M3) finansal sektör alanında uzmanlaşmış bu iki denetim şirketi tarafından denetlenen bankaların beklenen kredi zararlarının ihtiyari kısmı diğerlerine göre anlamlı bir şekilde (p: $0,05)$ daha düşüktür $(-0,001)$. Dolayısıyla denetim firması uzmanlığı ile finansal raporlama kalitesi arasında anlamlı ve pozitif bir ilişsi gözlemlenmiş ve bu nedenle $\mathrm{H}_{2 \mathrm{~B}}$ reddedilememiştir. $\mathrm{Bu}$ çerçevede elde edilen sonuçlar literatürle (Kanagaretnam vd., 2010: 2320, DeBoskey ve Jiang, 2012, Magnis ve Iatridis, 2017) uyumludur. Benzer şekilde denetçi uzmanlığının finansal raporlama kalitesi üzerindeki marjinal olumlu etkisi de pozitiftir.

Son olarak analiz edilen ampirik modellerden "M4" çerçevesinde çalışma kapsamında denetim kalitesi ölçümünde kullanılan her iki aracı değişken (denetçi büyüklüğü ve denetçi uzmanlığı) de beraber dikkate alınmıştır. Öncelikle denetim kalitesine ilişkin her iki göstergenin beraber dikkate alınması ihtiyari tahakkuklar ile ihtiyari tahakkuk öncesi net kar arasındaki ilişkiyi anlamlı bir şekilde azaltmıştır. "M4" kapsamında elde edilen sonuçlar diğer modeller ile kıyaslandığında beklenen zarar karşılıkları giderleri ile karşılık öncesi net kar arasındaki ilişkinin \%10 istatistiksel anlamlılık düzeyinde anlamlı olduğu gözlemlenmiştir. Dolayısıyla "Büyük Dört" denetim şirketi ve aynı zamanda finansal sektör alanında uzman denetim şirketleri (PwC ve KPMG) tarafindan denetlenen bankalarda kar yönetimi uygulamaları anlamlı seviyede düşüş göstermiştir. Bu çerçevede denetim kalitesi ile finansal raporlama kalitesi arasında anlamlı bir ilişki olduğunu test eden $\mathrm{H}_{2}$ reddedilememiştir. Diğer taraftan denetim kalitesine ilişkin her iki göstergenin de dikkate alındığı bu modelde, özellikle son dönemlerde yapılan çalışmalarla (Kanagaretnam vd., 2010, DeBoskey ve Jiang, 2012) benzer bir şekilde denetçi büyüklüğü değişkeni anlamlılığını kaybederken denetçi uzmanlığının finansal raporlama kalitesi üzerindeki baskın ve istatistiksel olarak anlamlı etkisi ortaya çıkmıştır. Dolayısıyla, ayrı olarak dikkate alındığında finansal raporlama kalitesi üzerinde denetçi büyüklüğü ve denetçi uzmanlığının pozitif etkisi söz konusuyken, iki değişken beraber dikkate alındığında denetçi uzmanlığı denetçi büyüklüğünün etkisini ortadan kaldırmıştır.

Diğer taraftan sermaye yönetimi kontrol değişkeni olarak modellere eklenen sermaye yeterlilik oranı test edilen bütün modellerde istatistiksel olarak anlamlı ve negatif çıkmıştır. $\mathrm{Bu}$ durum Basel düzenlemeleri sonrasında sermaye yönetimi ve ihtiyari tahakkuklar arasındaki ilişkiyi ölçen çalışmalarla uyum göstermektedir (Anandarajan vd., 2005, Bouvatier ve Lepetit, 2008, Leventis vd., 2011, Magnis ve Iatridis, 2017). Dolayisıyla, 2003-2018 dönemi için finansal verileri incelenen ve Türkiye'de faaliyet gösteren bankaların beklenen zarar karşılıkları aracılığıyla sermaye yeterlilik oranında birtakım düzeltmeler yaptıkları, bir diğer ifadeyle sermaye yönetimi uygulamalarında bulunulduğu söylenebilir.

Sonuçlar toplu olarak değerlendirildiğinde ise denetim kalitesinin beklenen zarar karşılıklarının ihtiyari kısmı üzerinde kısıtlayıcı bir etkisi olduğu gözlemlenmiş ve $\mathrm{H}_{2}$ reddedilememiştir. Bir diğer ifadeyle, incelenen 2003-2018 dönemi için Türkiye'de faaliyet gösteren bankalar için dikkate alındığında, denetim kalitesinin kar yönetimi uygulamaları üzerinde kısitlayıc1 ve bu nedenle finansal raporlama kalitesi üzerinde olumlu etkisi bulunmaktadir. 


\subsection{Doğrulayıcı Ek Analizler}

Çalışma kapsamında yapılan panel regresyon analizi kapsamında bazı ek analizler de gerçekleştirilmiştir. Öncelikle finansal sektör kar yönetimi çalışmaları incelendiğinde bu çalışmada test edilen iki aşamalı modellere ek olarak doğrudan beklenen zarar karş̧lıklarının (beklenen zarar karşılıkları giderlerinin) bağımlı değişken olarak kullanıldığı tek aşamalı yaklaşımlar (Beaver ve Engel, 1996) da bulunmaktadır. Bu kapsamda bağımlı değişken doğrudan "beklenen zarar karşılıkları giderleri" olarak da dikkate alınmış ve denetim kalitesi ölçütleri, kar yönetimi ölçütü ve diğer kontrol değişkenleri kapsamında model yeniden analiz edilmiştir. Elde edilen sonuçlara göre denetim firması büyüklüğü anlamlılı̆ını korurken denetim firmasının finansal sektör uzmanlığı ile finansal raporlama kalitesi arasında anlamlı bir ilişki gözlemlenememiştir. Beklenen zarar karşıllklarının doğrudan bağımlı değişken olarak alınması durumunda tahakkukların ihtiyari kısmının ayrıştırılmaması bankaların normal faaliyetleri ve riskler çerçevesinde ayırması gereken karşılıkların da kar yönetimi aracı oalrak kullanıldığı gibi bir yanılsamaya yol açabileceği gözen kaçırılmamalıdır. Bu kapsamda da yapılan çalışmalar iki aşamalı modellerin güvenilirlik ve geçerliliğinin daha yüksek olduğu şeklindedir (McNichols, 2001).

Ek olarak, analiz edilen temel modele 2008 finansal krizinin etkisini görmek amaciyla kukla değişkenler atanmış (2009-2012 dönemi "1", diğer dönemler "0")ve kriz döneminde ihtiyari tahakkukların kullanımında anlamlı bir değişiklik olup olmadığı sorgulanmıştır. Elde edilen sonuçlara göre kriz döneminde "Büyük Dört" denetim firması tarafından denetlenen bankaların ihtiyari tahakkukları diğerlerine göre daha düşük olarak gözlemlenmiştir. Denetçi uzmanlığı ile kar yönetimi uygulamaları arasında ise kriz dönemi için anlamlı bir ilişki gözlemlenememiş̧tir.

Diğer taraftan literatürde yapılan çalışmalar incelendiğinde çoğu çalışmada doğrudan net karın dikkate alınarak analizlerin vergi sonrası kar ekseninde yapıldığı görülmüş ve bu çalışmada da vergi sonra kar tutarı kullanılmıştır. Ancak, analizler vergi öncesi kar için yeniden tekrar edildiğinde sonuçlarda anlamlı bir ayrışmaya rastlanılmamıştır. Son olarak model havuzlanmış regresyon modeli (pooled regression) ile de tahmin edilmiş ancak elde edilen sonuçlardan farklı bir sonuç elde edilmemiştir.

\section{SONUÇ}

Gerek milli gerek global ekonomi çerçevesinde oldukça büyük bir öneme sahip olan ve finansal sektörün en önemli yapı taşı olarak karşımıza çıkan bankacılık sektörü ekseninde yapılan bağımsız denetime ilişkin çalışmalar ne yazık ki çok kısıtlıdır. Bu kapsamda finansal raporlama kalitesi ve denetim kalitesi arasındaki ilişkiyi gün yüzüne çıkarmanın gerek literatüre gerek piyasa katılımcıları ve düzenleyici otoritelere fayda sağlaması beklenmektedir. Bankacıllk sektörü dinamikleri ve işleyiş mekanizmaları bakımından diğer sektörlerden ayrışmakta olup, bu durum, bankaların geçtiği bağımsız denetim sürecini de klasik denetim anlayışından ayrıştırmaktadır. Bu kapsamda finansal raporlama kalitesi ve denetim kalitesi ve bu iki unsurun kesişimi noktasında finansal sektörün diğer sektörlerden ayrı olarak ele alınması önem arz etmektedir.

Yapılan bu çalışma kapsamında Türkiye'de faaliyet gösteren 22 bankanın 2003-2018 yıllarına ait finansal tablo verileri finansal raporlama kalitesi ve denetim kalitesi ekseninde 
incelenmiştir. Finansal raporlama kalitesi "karın istikrarlı gösterilmesi" kar yönetimi uygulaması, denetim kalitesi ise denetçi büyüklüğü ve denetçi uzmanlığı çerçevesinde ele alınmıştır. Elde edilen sonuçlara göre analiz edilen dönem için Türk bankacılık sektörünü oluşturan bankalar (yatırım ve kalkınma bankaları) "beklenen zarar karşılıkları" aracılığıyla karın istikrarlı gösterilmesi şeklinde ortaya çıkan kar yönetimi davranışını göstermektedirler. Denetim kalitesinin kar yönetimi uygulamaları kapsamında ölçülen finansal raporlama kalitesi üzerinde ise etkisi olumlu yöndedir. Bu kapsamda elde edilen sonuçlara göre denetim kalitesi, ihtiyari tahakkukların kullanımını azaltmakta, bir diğer ifadeyle kar yönetim davranışını baskılayarak finansal raporlama kalitesini arttırmaktadır. Denetim kalitesi kapsamında ele alınan denetçi büyüklüğü ve denetçi uzmanlığı ayrı olarak analiz edildiğinde iki göstergenin de kar yönetimini azalttığı gözlemlenmiştir. Diğer taraftan denetim kalitesi ölçüm değişkenleri eş zamanlı analize sokulduğunda ise, denetim kalitesinin finansal raporlama kalitesini arttırdığı; ancak bu artışın denetçi uzmanlığı ekseninde gerçekleştiği ortaya konulmuştur. Dolayısıyla, finansal sektör üzerinde uzmanlaşan bağımsız denetim firmalarının bu sektördeki karmaşık sistemleri daha iyi çözümlediği, hileli muhasebeleştirme uygulamalarının kullanımı önünde önemli bir engel oluşturarak, finansal raporlama kalitesine olumlu katkılar yaptığı söylenebilir.

Çalışmanın sonuçları değerlendirilirken birtakım kısıtlılıklar da dikkate alınmalıdır. $\mathrm{Bu}$ çalışmanın en önemli kısıtı veri erişim sürecinden kaynaklanmaktadır. Özellikle beklenen zarar karşılıklarının tahmininde kullanılan "aktiften silinen krediler" kalemi ne yazık ki örneklemdeki tüm bankalar için mevcut değildir. Diğer taraftan sadece Türkiye'de faaliyet gösteren bankaların analize dahil edilmesi de çalışma sonuçlarının yurt dışı literatürle uyumlu olsa bile geçerliliği üzerinde kısıt oluşturmaktadır. Son olarak kar yönetimi literatürü incelendiğindiğinde modelleme konusunda hala bir görüş birliği bulunmadığı görülebilir. $\mathrm{Bu}$ çerçevede beklenen zarar karşılıklarının tahmininde tek/iki aşamalı model tartışmasının yanında tahakkukların dikkate alınmasında bilanço (beklenen zarar karşılıklar)/gelir tablosu (beklenen zarar karşılıkları giderleri) yaklaşımlarının hangisinin kullanılması gerektiği konusu da hala tartışmalıdır. Bu çalışma kapsamında gelir tablosu yaklaşımı benimsenmiş ve ihtiyari tahakkukların tahmininde beklenen zarar karşılıkları giderleri dikkate alınmıştır. Yapılacak diğer çalışmalar bilanço yaklaşımını dikkate alabilir ve bu iki yaklaşımı kıyaslayarak modelleme alanına pozitif katkı sağlayabilir. Denetim kalitesinin ölçümünde aracı değişken olarak dikkate alınan denetçinin sektörel uzmanlığının tespitinde ise geniş bir kullanım alanı olan GAO raporu dikkate alınmıştır. Bu kabul sadece bir varsayımdır ve ayrıştırılan diğer denetim firmalarının finansal sektörde kötü performans gösterdikleri şeklinde yorumlanmamalıdır. Bu çerçevede yapılması planlanan diğer çalışmalar denetçi uzmanlığını denetim şirketlerinin pazar payları ya da denetim şirketinin müşteri portföyünün sektörel dağılımını dikkate alarak yeniden kurgulayabilirler. Gelecek çalışma önerilerine ek olarak ise, test edilen ampirik modelin geliştirilmesi (özellikle tahakkukların ihtiyari kısmının tahmini aşamasında), çalışmanın gelişmekte olan ekonomiler ekseninde genişletilerek test edilmesi, denetim kalitesi ölçümüne ilişkin yeni değişkenlerin tanımlanması ve test edilmesi, finansal raporlama kalitesinin başka ölçütler aracılığıyla da ölçülebilmesi yönünde yeni araştırma tasarımlarının yapılması ve bankacılık sektörü içinde de kendine has dinamikleri ile ayrışan kalkınma ve yatırım bankaları için de çalışmanın ayrıca tasarlanması ve analiz edilmesi sunulabilir. 


\section{KAYNAKLAR}

Abata, Matthew Adeolu (2015), “The Impact of International Financial Reporting Standards (IFRS) Adoption on Financial Reporting Practice in the Nigerian Banking Sector”, Journal of Policy and Development Studies, 289 (1850), pp. 1-16.

Abbott, Lawrence J.- Daugherty, Brian - Parker, Susan - Peters, Gary F. (2016), "Internal Audit Quality and Financial Reporting Quality: The Joint İmportance Of Independence And Competence”, Journal of Accounting Research, 54 (1), pp. 3-40.

Abu-Serdaneh, Jamal (2018), "Bank Loan-Loss Accounts, Income Smoothing, Capital Management, Signaling and Procyclicality: Evidence from Jordan”, Journal of Financial Reporting and Accounting, 16 (4), pp. 677-693.

Ahmed, Anwer S. - Takeda, Carolyn - Thomas, Shawn (1999). "Bank Loan Loss Provisions: A Reexamination of Capital Management, Earnings Management and Signaling Effects”, Journal of Accounting and Economics, 28 (1), pp. 1-25.

AICPA, 2006. Large Firm PCAOB Inspection Deficiency Analysis. <http:// www.aicpa.org/cpcaf/download/

PCAOB_Inspection_Deficiency_Analysis_January2006.pdf>

Akdoğan, Nalan - Bülbül, Samet (2019), "Bağımsız Denetçi Raporlarında Kilit Denetim Konularının Bildirilmesinde BİST 100 Şirketlerindeki İlk Uygulama Sonuçlarının Değerlendirmesine Yönelik Bir Araştırma. Muhasebe ve Denetime Bakis”, Accounting \& Auditing Review, 18 (56), ss. 1-24.

Ali, Ashraf - Hassan, Kabir M - Basher, Syed Abul (2015), "Loan Loss Provisioning in OIC Countries: Evidence From Conventional vs. Islamic Banks", Journal of King Abdulaziz University: Islamic Economics, 28 (1), pp: 23-59.

Anandarajan, Asokan - Hasan, Iftekhar - Lozano-Vivas, Ana (2005), "Loan Loss Provision Decisions: An Empirical Analysis of the Spanish Depository Institutions”, Journal of International Accounting, Auditing and Taxation, 14 (1), pp. 55-77.

Anderson, Ronald C. - Fraser, Donald R. (2000), "Corporate Control, Bank Risk Taking, and The Health of the Banking Industry”, Journal of Banking \& Finance, 24 (8), pp. 13831398.

Ashbaugh, Hollis - LaFond, Ryan - Mayhew, Brian W. (2003), "Do Nonaudit Services Compromise Auditor Independence? Further Evidence”, The Accounting Review, 78 (3), pp. 611-639.

Balsam, Steven - Krishnan, Jagan - Yang Joon S. (2003), "Auditor Industry Specialization and Earnings Quality”, Auditing: A Journal of Practice and Theory, 22 (2), pp. 71-97. 
Baltagi, Badi (2008), Econometric Analysis of Panel Data. John Wiley \& Sons.

Bao, Ben-Hsien - Bao, Da-Hsien (2004), "Income Smoothing, Earnings Quality and Firm Valuation”, Journal of Business Finance \& Accounting, 31( 9-10), pp. 1525-1557.

Barth, Mary E - Landsman, Wayne R. (2010), "How Did Financial Reporting Contribute To The Financial Crisis?”, European Accounting Review, 19 (3), pp. 399-423.

Basu, S., L. S. Hwang, and C. L. Jan. 2000. Differences in Conservatism Between Big 8 and non-Big 8 Auditors, Working paper, City University of New York.

Beatty, Anne - Chamberlain, Sandra L. - Magliolo, Joseph (1995), "Managing Financial Reports of Commercial Banks: The Influence of Taxes, Regulatory Capital, and Earnings”, Journal of Accounting Research, 33 (2), pp. 231-261.

Beaver, William H. - Engel, Ellen E. (1996), "Discretionary Behavior with Respect to Allowances for Loan Losses and the Behavior of Security Prices”, Journal of Accounting and Economics, 22 (1), pp. 177-206.

Bedard, Jean C - Biggs, Stanley F. (1991), “The Effect of Domain-Specific Experience on Evaluation of Management Representations in Analytical Procedures”, Auditing: A Journal of Practiceand Theory, 10 (Supplement), pp. 77-90.

Beidleman, Carl R. (1973), "Income Smoothing: The Role of Management", The Accounting Review, 48, pp.653-667.

Bernanke, Ben S. (1983), "Nonmonetary Effects of the Financial Crisis in the Propagation of the Great Depression”, National Bureu of Economic Research, w1054, pp. 257-276.

Biddle, Gary C. - Hilary, Gilles - Verdi, Rodrigo S. (2009), "How Does Financial Reporting Quality Relate to Investment Efficiency?”, Journal of Accounting and Economics, 48 (2-3), pp. 112-131.

Billingsley, Randall S - Schneller, Meir I (2009), "Information Uncertainty and Auditor Reputation”, Journal of Banking and Finance, 33 ( 2), pp. 183-192.

Blasco, Natividad - Pelegrin, Begona (2006), “A New Methodological Approach for Detecting Income Smoothing in Small Samples: An Application to the Case of Spanish Savings Banks”, Journal of Accounting, Auditing \& Finance, 21 (4, pp. 347372.

Bouvatier, Vincent - Lepetit, Laetitia (2008), “Banks' Procyclical Behavior: Does Provisioning Matter?”, Journal of International Financial Markets, Institutions and Money, 18 (5), pp. 513-526.

Bratten, Brian - Causholli, Monika - Myers, Linda A. (2017), "Fair Value Exposure, Auditor Specialization, and Banks' Discretionary Use of the Loan Loss Provision”, Journal of Accounting, Auditing \& Finance, DOI: 0148558X17742567, pp. 1-31. 
Bratten, Brian - Causholli, Monika - Omer, Thomas C. (2019), “Audit Firm Tenure, Bank Complexity, and Financial Reporting Quality”, Contemporary Accounting Research, 36 (1), pp. 295-325.

Breton, Gaetan - Stolowy, Herve (2000), "A Framework for the Classification of Accounts Manipulations", HEC Accounting \& Management Control Working Paper, 708, pp. 194.

Burnett, Brian M. - Cripe, Bradrick M. - Martin, Gregory W - McAllister, Brian P. (2012), "Audit Quality and the Trade-Off between Accretive Stock Repurchases and AccrualBased Earnings Management”, The Accounting Review, 87 (6), pp. 1861-1884.

Bushman, Robert M. (2014), “Thoughts on Financial Accounting and the Banking Industry”, Journal of Accounting and Economics, 58 (2), pp. 384-395.

Carcello, Joseph V.- Nagy, Albert L. (2003), “Client Size, Auditor Specialization and Fraudulent Financial Reporting”, Managerial Auditing Journal, 19 (5), pp. 651-668.

Cavallo, Michele - Majnoni, Giovanni (2002), Do banks provision for bad loans in good times? Empirical evidence and policy implications, Springer, Boston, MA.

Chalermchatvichien, Pichaphop - Jumreornvong, Seksak - Jiraporn, Pornsit - Singh, Manohar (2014), "The Effect of Bank Ownership Concentration on Capital Adequacy, Liquidity, and Capital Stability”, Journal of Financial Services Research, 45 (2), pp. 219-240.

Chen, Huifa - Tang, Qingliang - Jiang, Yihong - Lin, Zhijun (2010), "The Role of International Financial Reporting Standards in Accounting Quality: Evidence from the European Union”, Journal of International Financial Management \& Accounting, 21 (3), pp. 220-278.

Chen, Hanwen- Chen, Jeff Z. - Lobo, Gerald J. - Wang, Yanyan (2011), "Effects of Audit Quality on Earnings Management and Cost of Equity Capital: Evidence From China”, Contemporary Accounting Research, 28 (3), pp. 892-920.

Chen, Feng - Hope, Ole Kristian - Li, Qingyuan - Wang, Xin (2011), "Financial Reporting Quality and Investment Efficiency of Private Firms in Emerging Markets", The Accounting Review, 86 (4), pp. 1255-1288.

Cohen, Jeffrey R. - Krishnamoorthy, Ganesh- Wright, Arnold (2004), “The Corporate Governance Mosaic and Financial Reporting Quality”, Journal of Accounting Literature, pp. 87-152.

Collins, Julie H. - Shackelford, Douglas A. - Wahlen, James M. (1995), "Bank Differences in the Coordination of Regulatory Capital, Earnings, And Taxes”, Journal of Accounting Research, 33 (2), pp. 263-291.

Copeland, Ronald M. (1968), Income smoothing. Journal of Accounting Research, 101-116. 
Craswell, Allen T. - Francis, Jere R. - Taylor, Stephen L. (1995), “Auditor Brand Name Reputations and Industry Specializations”, Journal of Accounting and Economics, 20 (3), pp. 297-322.

Curcio, Domenico - Hasan, Iftekhar (2015), "Earnings and Capital Management and Signaling: The Use of Loan-Loss Provisions by European Banks", The European Journal of Finance, 21 (1), pp. 26-50.

Dahl, Drew - O’Keefe, John P. - Hanweck, Gerald A. (1998), “The Influence of Examiners and Auditors on Loan-Loss Recognition”, FDIC Banking Review, 11, pp. 10-25.

Dal Maso, Lorenzo - Kanagaretnam, Kiridaran - Lobo, Gerald J. - Terzani, Simone (2018), "The Influence Of Accounting Enforcement on Earnings Quality of Banks: Implications of Bank Regulation and the Global Financial Crisis”, Journal of Accounting and Public Policy, 37 (5), pp. 402-419.

DeAngelo, Linda E. (1981), “Auditor size and audit quality”, Journal of Accounting and Economics, 3 (3), pp. 183-199.

DeBoskey, David G. - Jiang, Wei (2012), “Earnings Management and Auditor Specialization in the Post-Sox Era: An Examination of the Banking Industry”, Journal of Banking \& Finance, 36 (2), pp. 613-623.

Dechow, Patricia M. - Skinner, Douglas J. (2000), "Earnings Management: Reconciling the Views of Accounting Academics, Practitioners, and Regulators", Accounting horizons, 14 (2), pp. 235-250.

Dechow, Patricia M. - Myers, Linda A.- Shakespeare, Catherine (2010), "Fair Value Accounting and Gains From Asset Securitizations: A Convenient Earnings Management Tool with Compensation Side-Benefits”, Journal of Accounting and Economics, 49 (1), pp. 2-25.

DeFond, Mark L.- Jiambalvo, James (1994), "Debt Covenant Violation and Manipulation of Accruals", Journal of Accounting and Economics, 17, pp.145-176.

DeFond, Mark L.- Park, Chul W. (1997), "Smoothing Income in Anticipation of Future Earnings", Journal of Accounting and Economics, 23, pp.115-139.

DeFond, Mark L. - Zhang, Jieying (2013), “A reivew of archival auditing research”, Journal of Accounting and Economics, 58 (2-3), pp. 275-326.

Delis, Manthos D., Hasan, Iftekhar- Iosifidi, Maria - Li, Lingxiang (2018). “Accounting Quality in Banking: The Role of Regulatory Interventions”, Journal of Banking \& Finance, 97, pp. 297-317.

Dopuch, Nicholas - Simunic, Dan (1982), “Competition in Auditing: An Assessment”, Paper presented at Symposium on Auditing Research IV, University of Illinois at UrbanaChampaign. 
Doyle, Jeffrey T. - Ge, Weili - McVay, Sarah (2007), “Accruals Quality and Internal Control over Financial Reporting”, The Accounting Review, 82 (5), pp. 1141-1170.

Dunn, Kimberly A. - Mayhew, Brian W. (2004), “Audit Firm İndustry Specialization and Client Disclosure Quality”, Review of Accounting Studies, 9 (1), pp. 35-58.

El Sood, Heba Abou (2012), "Loan loss provisioning and income smoothing in US banks pre and post the financial crisis", International Review of Financial Analysis, 25, pp. 6472.

Elder, Randal J. - Lowensohn, Suzanne - Reck, Jacqueline L. (2015), “Audit Firm Rotation, Auditor Specialization, and Audit Quality in the Municipal Audit Context”, Journal of Government \& Nonprofit Accounting, 4 (1), pp. 73-100.

Erdoğan, Ali (2014), "Basel Kriterlerinin Bankacıllk Sektörüne Etkisi ve Türkiye'de Bankacılık Sektörünün Basel Kriterlerine Uyum Süreci”, Trakya University Journal of Social Science, 16 (1), ss. 141-182.

Fonseca, Ana Rosa - Gonzalez, Francisco (2008), “Cross-Country Determinants of Bank Income Smoothing by Managing Loan-Loss Provision”, Journal of Banking \& Finance, 32 (2), pp. 217-228.

Francis, Jere R.- Maydew, Edward L. - Sparks, Charles (1999), “The Role of Big 6 Auditors in the Credible Reporting of Accruals”, Auditing: A Journal of Practice and Theory, 18 (2), pp. 17-34.

Francis, Jere R.- Reichelt, Kenneth - Wang, Dechun. (2005), "The Pricing of National and City-Specific Reputations for Industry Expertise in the U.S. Audit Market”, The Accounting Review, 80 (1), pp. 113-36.

Francis, Jere R. - Yu, Michael D. (2009), “Big 4 Office Size and Audit Quality”, The Accounting Review, 84 (5), pp. 1521-1552.

Frankel, Richard M. - Johnson, Marilyn F.- Nelson, Karen K. (2002), “The Relation Between Auditors' Fees for Nonaudit Services and Earnings Management”, The Accounting Review, 77, Supplement, pp. 71-105

Fudenberg, Drew - Tirole, Jean (1995), “A Theory of Income and Dividend Smoothing Based on Incumbency Rents”, Journal of Political Economy, 103 (1), pp. 75-93.

Gaynor, Lisa M.- Kelton, Andrea Seaton - Mercer, Molly - Yohn, Teri Lombardi (2016), "Understanding The Relation Between Financial Reporting Quality and Audit Quality”, Auditing: A Journal of Practice \& Theory, 35 (4), pp. 1-22.

Gençoğlu, Ümit Gücenme - Ertan, Yasemin (2012), “Muhasebe Kalitesini Etkileyen Faktörler ve Türkiye'deki Durum”, Muhasebe ve Finansman Dergisi, Sayı 53, Ocak, ss. 1-24. 
General Accounting Office (GAO) (1991), Failed Banks: Accounting and Auditing Reforms Urgently Needed. GAO/AFMD, 91 (43), pp.30.

General Accounting Office (GAO) (2003), Public Accounting Firms: Mandated Study on Consolidation and Competition. Washington, DC.

Greenawalt, Mary Brady - Sinkey, Joseph F (1988), "Bank Loan-Loss Provisions and the Income-Smoothing Hypothesis: An Empirical Analysis, 1976-1984”, Journal of Financial Services Research, 1 (4), pp. 301-318.

Gujarati, Damodar N. (2009), Basic Econometrics. Tata McGraw-Hill Education.

Habbash, Murya - Alghamdi, Salim (2017), “Audit Quality and Earnings Management in Less Developed Economies: The Case of Saudi Arabia”, Journal of Management \& Governance, 2 (2), pp. 351-373.

Hasan, Iftekhar - Wall, Larry D. (2004), “Determinants of the Loan Loss Allowance: Some Cross-Country Comparisons”, Financial Review, 39 (1), pp. 129-152.

Healy, Paul M. - Wahlen, James M. (1999), “A Review of the Earnings Management Literature and its Implications for Standard Setting”, Accounting Horizons, 13 (4), pp. 365-383.

Hoitash, Rani - Markelevich, Ariel - Barragato, Charles A. (2007), “Auditor Fees and Audit Quality”, Managerial Auditing Journal, 22 (8), pp. 761-786.

Huang, Der-Fen - Wang, Chao - Lan (2013), “Book-Tax Differences and Earnings Quality for the Banking Industry: Evidence From Taiwan”, Pacific Accounting Review, 25 (2), pp. 145-164.

Huizinga, Harry - Laeven, Luc (2012), “Bank Valuation and Accounting Discretion During a Financial Crisis”, Journal of Financial Economics, 106 (3), pp. 614-634.

Iatridis, George (2010), “International Financial Reporting Standards and the Quality of Financial Statement information”, International Review of Financial Analysis, 19 (3), pp. 193-204.

Imhoff, Eugene A. (1975), “Income Smoothing: The Role of Management: A Comment”, The Accounting Review, 50 (1), pp. 118-121.

Jenkins, David S. - Velury, Uma (2008), "Does Auditor Tenure Influence the Reporting of Conservative Earnings?”, Journal of Accounting and Public Policy, 27 (2), pp. 115132.

Jin, Justin Yiqiang - Kanagaretnam, Kiridaran - Lobo, Gerald J. (2011), “Ability of Accounting and Audit Quality Variables to Predict Bank Failure During the Financial Crisis”, Journal of Banking \& Finance, 35 (1)1, pp. 2811-2819. 
Johnson, Van E. - Khurana, Inder K. - Reynolds, J. Kenneth (2002), “Audit-Firm Tenure and the Quality of Financial Report”, Contemporary Accounting Research, 19 (4), pp. 637660 .

Jonas, Gregory J. - Blanchet, Jeannot (2000), ”Assessing Quality of Financial Reporting”, Accounting Horizons, 14 (3), pp. 353-363.

Jordan, Charles E. - Clark, Stanley J.- Hames, Charlotte, C. (2010), “The Impact Of Audit Quality on Earnings Management to Achieve User Reference Points in EPS”, Journal of Applied Business Research, 26 (1), pp. 19-30.

Kamu Gözetimi Kurumu. (2018), Finansal Raporlamaya İlişkin Kavramsal Çerçeve, https://www.kgk.gov.tr

Kanagaretnam, Kiridaran - Lobo, Gerald J. - Mathieu, Robert (2003), “Managerial Incentives for Income Smoothing through Bank Loan Loss Provisions”, Review of Quantitative Finance and Accounting, 20 (1), pp. 63-80.

Kanagaretnam, Kiridaran - Lobo, Gerald J. - Yang, Dong-Hoon (2004), “Joint Tests of Signaling and Income Smoothing through Bank Loan Loss Provisions”, Contemporary Accounting Research, 21 (4), pp. 843-884.

Kanagaretnam, Kiridaran - Krishnan, Gopal V. - Lobo, Gerald J. (2009), "Is the Market Valuation of Banks' Loan Loss Provision Conditional on Auditor Reputation?”, Journal of Banking \& Finance, 33 (6), pp. 1039-1047.

Kanagaretnam, Kiridaran - Lim, Chee Yeow - Lobo, Gerald J. (2010), “Auditor Reputation and Earnings Management: International Evidence from the Banking Industry", Journal of Banking \& Finance, 34 (1)0, pp. 2318-2327.

Kanagaretnam, Kiridaran - Krishnan, Gopal V. - Lobo, Gerald J. - Mathieu, Robert (2011), “Audit Quality and the Market Valuation of Banks' Allowance for Loan Losses”, Accounting Perspectives, 10 (3), pp. 161-193.

Kim, Myung-Sun- Kross, William (1998), “The Impact of the 1989 Change in Bank Capital Standards on Loan Loss Provisions and Loan Write-Offs”, Journal of Accounting and Economics, 25 (1), pp. 69-99.

Kim, Jeong-Bon - Chung, Richard - Firth, Michael (2003), “Auditor Conservatism, Asymmetric Monitoring, and Earnings Management”, Contemporary Accounting Research, 20 (2), pp. 353-359.

Kinney, William R. - Libby, Robert (2002), "Discussion of the Relation Between Auditors' Fees for Nonaudit Services and Earnings Management”, The Accounting Review, 77, Supplement, pp. 107-14.

Knechel, W. Robert (2009), “Audit Lessons from the Economic Crisis: Rethinking Audit Quality”, Working paper, Maastricht University. 
Knechel, W. Robert (2016), “Audit Quality and Regulation”, International Journal of Auditing, 20 (3), pp. 215-223.

Knechel, W. Robert - Niemi, Lasse - Zerni, Mikko (2013), "Empirical Evidence on the Implicit Determinants of Compensation In Big 4 Audit Partnerships”, Journal of Accounting Research, 51 (2), pp. 349-387.

Krishnan, Gopal V. (2003a), “Audit Quality and the Pricing of Discretionary Accruals”, Auditing: A Journal of Practice and Theory, 22 (1), pp. 109-126.

Krishnan, Gopal V. (2003b), “Does Big 6 Auditor Industry Expertise Constrain Earnings Management?” Accounting Horizons, 17, Supplement, pp. 1-16.

Krishnan, Gopal V. (2005), “The Association Between Big 6 Auditor Industry Expertise and the Asymmetric Timeliness of Earnings”, Journal of Accounting, Auditing and Finance, Summer, pp. 20-28.

Krishnan, Gopal V. - Parsons, Linda M. (2008), "Getting to the Bottom Line: An Exploration of Gender and Earnings Quality”, Journal of Business Ethics, 78 (1-2), pp. 65-76.

Kwak, Wikil - Lee, Ho-Young - Mande, Vivek (2009), “Institutional Ownership and Income Smoothing by Japanese Banks through Loan Loss Provisions”, Review of Pacific Basin Financial Markets and Policies, 12 (2), pp. 219-243.

Leventis, Stergios - Dimitropoulos, Panagiotis E. - Anandarajan, Asokan (2011), "Loan Loss Provisions, Earnings Management and Capital Management under IFRS: The Case of EU Commercial Banks”, Journal of Financial Services Research, 40 (1-2), pp. 103122.

Lim, Chee-Yow - Tan, Hun-Tong (2008), "Non-Audit Service Fees and Audit Quality: The Impact Of Auditor Specialization”, Journal of Accounting Research, 46 (1), pp. 199246.

Lin, Jerry W. - Hwang, Mark I. (2010), “Audit Quality, Corporate Governance, and Earnings Management: A Metaanalysis”, International Journal of Auditing, 14 (1), pp. 57-77.

Lobo, Gerald J. - Yang, Dong-Hoon (2001), "Bank Managers' Heterogeneous Decisions on Discretionary Loan Loss Provisions”, Review of Quantitative Finance and Accounting, 16 (3), pp. 223-250.

Lowensohn, Suzanne - Johnson, Laurance E. - Elder, Randal J. - Davies, Stephen P. (2007), "Auditor Specialization, Perceived Audit Quality, and Audit Fees in the Local Government Audit Market”, Journal of Accounting and Public Policy, 26 (6), pp. 705732.

Ma, Cristopher K. (1988), "Loan loss reserves and income smoothing: the experience in the US banking industry”, Journal of Business Finance \& Accounting, 15 (4), pp. 487497. 
Magnis, Chris - Iatridis, George E. (2017), "The Relation between Auditor Reputation, Earnings and Capital Management in the Banking Sector: An International Investigation”, Research in International Business and Finance, 39, pp.338-357.

Maijoor, Steven J. - Vanstraelen, Ann (2006), “Earnings Management within Europe: The Effects of Member State Audit Environment, Audit Firm Quality and International Capital Markets”, Accounting and Business Research, 36 (1), pp. 33-52.

Maletta, Mario - Wright, Arnold (1996), “Audit Evidence Planning: An Examination of Industry Error Characteristics”, Auditing: A Journal of Practice and Theory, 15 (1), pp. 71-86.

Martinez, Antonio Lopo- Castro, Miguel (2011), "The Smoothing Hypothesis, Stock Returns and Risk in Brazil", BAR-Brazilian Administration Review, 8, pp.1-20.

McNichols, Maureen - Wilson, G. Peter (1988), “Evidence of Earnings Management from the Provision for Bad Debts”, Journal of Accounting Research, 26, pp.1-31.

McNichols, Maureen (2001), "Research Design Issues in Earnings Management Studies”, Journal of Accounting and Public Policy, 19 (4), pp. 313-345.

Michelson, Stuart E.- Jordan-Wagner, James - Wootton, Charles W. (1995), "A Market Based Analysis of Income Smoothing", Journal of Business Finance \& Accounting, 22, pp. 1179-1193.

Mulford, Charles W. - Comiskey, Eugene E. (2011). The Financial Numbers Game: Detecting Creative Accounting Practices: John Wiley \& Sons.

Myers, James N. - Myers, Linda A. - Omer, Thomas C. (2003), "Exploring the Term of the Auditor-Client Relationship and Quality of Earnings: A Case For Mandatory Auditor Rotation?”, The Accounting Review, 78 (3), pp. 779-799.

Osma, Beatriz García - Mora, Araceli - Porcuna-Enguix, Luis (2019) “Prudential Supervisors' Independence and Income Smoothing in European Banks”, Journal Of Banking \& Finance, 2019, 102, pp. 156-176.

Ozili, Peterson K. (2018), "Bank Loan Loss Provisions, Investor Protection and the Macroeconomy”, International Journal of Emerging Markets, 13, 1, pp. 45-65.

Palmrose, Zoe-Vonna (1988), "Analysis of Auditor Litigation and Audit Service Quality”, The Accounting Review, 63 (1), pp. 55-73.

Reichelt, Kennth - Wang, Dechun (2010), "National and Office-Specific Measures of Auditor İndustry Expertise and Effects on Audit Quality”, Journal of Accounting Research, 48 (3), pp. 647-686.

Rivard, Richard J. - Bland, Eugene - Morris, Gay B. H. (2003), “Income Smoothing Behavior of US Banks under Revised International Capital Requirements”, International Advances in Economic Research, 9 (4), pp. 288-294. 
Scheiner, James H. (1981), "Income Smoothing: An Analysis in the Banking Industry", Journal of Bank Research, 12, pp. 1919-2123.

Shah, Ali - Butt, Safdar A. - Hassan, Aarshad (2009), “Corporate Governance and Earnings Management an Empirical Evidence from Pakistani Listed Companies”, European Journal of Scientific Research, 26 (4), pp. 624-638.

Song, Chang Joon - Thomas, Wayne B. - Yi, Han (2010), "Value Relevance of FAS No. 157 Fair Value Hierarchy Information and the Impact of Corporate Governance Mechanisms”, The Accounting Review, 85 (4), pp. 1375-1410.

Srinidhi, Bin N. - Gul, Ferdinand A. (2007), “The Differential Effects of Auditors’ Nonaudit and Audit Fees on Accrual Quality”, Contemporary Accounting Research, 24 (2), pp. 595-629.

Stolowy, Herve - Breton, Gaetan (2004), "Accounts Manipulation: A Literature Review and Proposed Conceptual Framework", Review of Accounting and Finance, 3, pp.5-92.

Teoh, Siew Hong - Wong, Tak J. (1993), "Perceived Auditor Quality and the Earnings Response Coefficient”, The Accounting Review, 68 (2), pp. 346-367.

Titman, Sheridan - Trueman, Brett (1986), "Information Quality and the Valuation of New Issues", Journal of Accounting and Economics, 8 (2), pp. 159-172.

Trueman, Brett - Titman, Sheridan (1988), "An Explanation for Accounting Income Smoothing", Journal of Accounting Research, 26, pp.127-139.

Uwuigbe, Uwalomwa - Emeni, Francis Kehinde - Uwuigbe, Olubukola Ranti - Maryjane, Ataiwrehe Chojakeme (2016), "IFRS Adoption and Accounting Quality: Evidence from the Nigerian Banking Sector", Journal of Corporate Ownership and Control, 9(4), pp. 187-196.

Vauhkonen, Jukka (2011), “The Impact of Pillar 3 Disclosure Requirements of Bank Safety”, Journal of Financial Services Research, 47 (1-2), pp. 37-49.

Venkataraman, Ramgopal - Weber, Joseph P. - Willenborg, Michael (2008), "Litigation Risk, Audit Quality, and Audit Fees: Evidence from Initial Public Offerings", The Accounting Review, 83 (5), pp. 1315-1345.

Vishnani, Sushma - Agarwal, Sonu - Agarwalla, Ritika - Gupta, Saumya (2019), "Earnings Management, Capital Management and Signalling Behaviour of Indian Banks”, AsiaPacific Financial Markets, 26, pp. 285-295.

Watts, Ross - Zimmerman, Jerold (1981), “The Markets for Independence and Independent Auditors”, The University of Rochester Working Paper Series, No. GPB 80-10.

Wright, Arnold - Wright, Sally (1997), “The Effect of Industry Experience on Hypothesis Generation and Audit Planning Decisions”, Behavioral Research in Accounting, 9, pp. 273-294. 
Yanık, Serap - Karataş, Muharrem (2017), "Denetim Raporlarının Geleceği: Yeni Düzenlemeler Ve Ülke Uygulamaları”, Muhasebe ve Finansman Dergisi, 73, ss. 1-26. 
